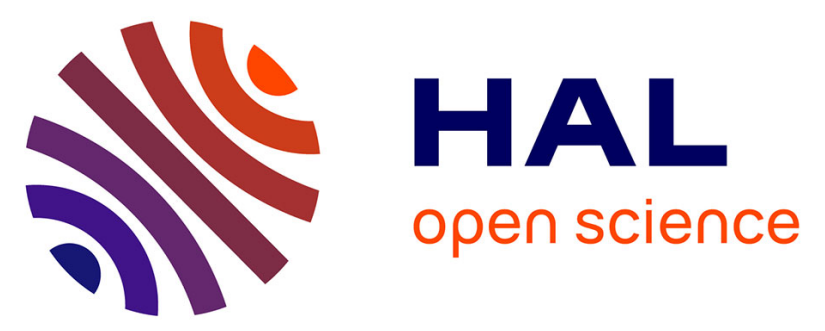

\title{
Heat flux-based strategies for the thermal monitoring of sub-fumarolic areas: Examples from Vulcano and La Soufrière de Guadeloupe
}

\author{
Damien Gaudin, Tullio Ricci, Anthony Finizola, Eric Delcher, Salvatore \\ Alparone, Stéphanie Barde-Cabusson, Élodie Brothelande, Fabio Di Gangi, \\ Salvatore Gambino, Salvatore Inguaggiato, et al.
}

\section{To cite this version:}

Damien Gaudin, Tullio Ricci, Anthony Finizola, Eric Delcher, Salvatore Alparone, et al.. Heat fluxbased strategies for the thermal monitoring of sub-fumarolic areas: Examples from Vulcano and La Soufrière de Guadeloupe. Journal of Volcanology and Geothermal Research, 2017, 343, pp.122 - 134. 10.1016/j.jvolgeores.2017.06.021 . hal-01906614

\section{HAL Id: hal-01906614 \\ https://hal.univ-reunion.fr/hal-01906614}

Submitted on 7 Nov 2018

HAL is a multi-disciplinary open access archive for the deposit and dissemination of scientific research documents, whether they are published or not. The documents may come from teaching and research institutions in France or abroad, or from public or private research centers.
L'archive ouverte pluridisciplinaire HAL, est destinée au dépôt et à la diffusion de documents scientifiques de niveau recherche, publiés ou non, émanant des établissements d'enseignement et de recherche français ou étrangers, des laboratoires publics ou privés. 


\title{
Heat flux-based strategies for the thermal monitoring of sub-fumarolic areas: Examples from Vulcano and La Soufrière de Guadeloupe
}

\author{
Damien Gaudin a,b,*, Tullio Ricci a , Anthony Finizola ${ }^{c}$, Eric Delcher ${ }^{c}$, Salvatore Alparone ${ }^{\mathrm{d}}$, \\ Stéphanie Barde-Cabusson ${ }^{\mathrm{e}}$, Elodie Brothelande ${ }^{\mathrm{f}}$, Fabio Di Gangi ${ }^{\mathrm{g}}$, Salvatore Gambino ${ }^{\mathrm{d}}$, \\ Salvatore Inguaggiato ${ }^{\mathrm{g}}$, Vincenzo Milluzzo ${ }^{\mathrm{h}}$, Aline Peltier ${ }^{\mathrm{i}}$, Fabio Vita ${ }^{\mathrm{g}}$ \\ a Istituto Nazionale di Geofisica e Vulcanologia, via di Vigna Murata 605, 00143 Rome, Italy \\ b Ludwig-Maximilians-Universität München (LMU), Department of Earth \& Environmental Sciences, Theresienstr. 41, 80333 Munich, Germany

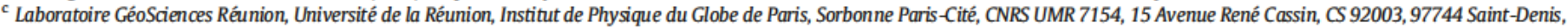 \\ La Réunion, France \\ d Istituto Nazionale di Geofisica e Vulcanologia, Osservatorio Etneo, Piazza Roma 2, 95125 Catania, Italy \\ e Instituto de Ciencias de la Tierra Jaume Almera-Consejo Superior de Investigaciones Científicas (ICTJA-CSIC), C/Lluís Solé i Sabarís s/n, 08028 Barcelona, Spain \\ ${ }^{\mathrm{f}}$ Department of Marine Geosciences, Rosenstiel School of Marine and Atmospheric Science, University of Miami, 4600 Rickenbacker Causeway, Miami, FL 33149, USA \\ ${ }^{g}$ Istituto Nazionale di Geofisica e Vulcanologia, Via Ugo La Malfa, 153, 90146 Palermo, Italy \\ ${ }^{\text {h }}$ Eni Angola, Avenida Lenine 58, Luanda, Angola

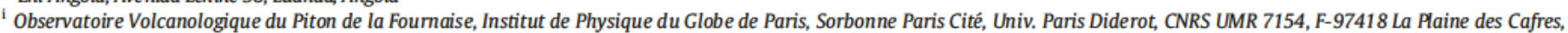 \\ La Réunion, France
}

\section{A B S T R A C T}

Although it is relatively easy to set-up, the monitoring of soil temperature in sub-fumarolic areas is quite rarely used to monitor the evolution of hydrothermal systems. Indeed, measurements are highly sensitive to environmental conditions, in particular daily and seasonal variations of atmospheric temperatures and rainfalls, which can be only partially filtered by the established statistical analysis. In this paper, we develop two innovative processing methods, both based on the computation of the heat flux in the soil. The upward heat flux method (UHF), designed for dry environments, consists in computing both the conductive and convective components of the heat flux between two thermocouples placed vertically. In the cases of wet environments, the excess of total heat method (ETH) allows the integration of rain gauges data in order to correct the heat balance from the super-ficial cooling effect of the precipitations. The performances of both processing techniques are faced to established methods (temperature gradient and coefficient of determination) on soil temperature time series from two test volcanoes. At La Fossa di Vulcano (Italy), the UHF method undoubtedly detects three thermal crises between 2009 and 2012, enabling to quantify not only the intensity but also the precise timing of the heat flux increase with respect to corresponding geochemical and seismic crises. At La Soufrière de Guadeloupe (French Lesser An-tilles), despite large rainfalls dramatically influencing the thermal behavior of the soil, a constant geothermal heat flux is retrieved by the ETH method, confirming the absence of fumarolic crisis during the observation period (FebruaryAugust 2010). Being quantitative, robust, and usable in almost any context of sub-fumarolic zones, our two heat flux-based methods increase the potential of soil temperature for the monitoring, but also the gen-eral interpretation of fumarolic crises together with geochemical and seismological observations. A spreadsheet allowing direct computation of UHF and ETH is provided as supplemental material.

\section{Introduction}

Hydrothermal systems are associated to numerous active and dor mant volcanoes in the world, e.g., to name some of the most famous

\footnotetext{
* Corresponding author at: Ludwig-Maximilians-Universität München (LMU), Department of Earth \& EnvironmentalSciences, Theresienstr. 41, 80333 Munich, Germany.

E-mail addresses: damgaudin@gmail.com, damien.gaudin@min,uni-muenchen,de (D. Gaudin).
}

ones, Yellowstone (Morgan et al., 1977), Campi Flegrei (Chiodini et al., 2001) or White Island (Giggenbach, 1987). They arise when hot water, either of magmatic or meteoric origin, rises up to the surface as liquid or steam (Harris and Stevenson, 1997). On the surface, they are associated to hot springs, hot lakes, mud pools, or diffuse degassing zones, that may be or not associated to thermal anomalies or fumarolic zones (Brown et al., 1989). The latter ones appear when steam reaches the vicinity of the surface. If the heat flux is large enough $\left(\geq 500 \mathrm{~W} / \mathrm{m}^{2}\right)$ fumaroles are visible and steam condensates in the atmosphere 
(Aubert, 1999; Gaudin et al., 2013). For weaker fluxes, atmosphere dra matically cools the most superficial layers of the ground and steam con denses mostly in the soil in the so called sub fumarolic zones (Aubert, 1999), and a significant fraction of the heat flux is transported to the surface by conduction (Sekioka and Yuhara, 1974; Gaudin et al., 2013, 2015; Ricci et al., 2015).

Monitoring hydrothermal systems has a twofold interest. First, the interactions of the hydrothermal system with the magma can be re sponsible for hazardous phreatic and phreatomagmatic explosions (Heiken et al., 1980; Bertagnini et al., 1991). Secondly, fumarolic crises have been reported prior to eruptions, as in La Soufrière de Guadeloupe (Jolivet, 1958), Mount St Helens (Kieffer et al., 1981), Mount Pelée (Chrétien and Brousse, 1989) and Vulcano (Chiodini et al., 1995). These fumarolic crises may include the increase of gas flux ("geochem ical crises"), the widening and the temperature increase of the fumarolic and sub fumarolic fields ("thermal crises"), and seismic swarms ("seis mic crises").

While numerous techniques have been used to monitor the gas flux of volcanoes in particular UV spectroscopy for the monitoring of $\mathrm{SO}_{2}$ fluxes (Edmonds et al., 2003; Aiuppa et al., 2005; Salerno et al., 2009; Vita et al., 2012), soil stations for the monitoring of $\mathrm{CO}_{2}$ degassing (Inguaggiato et al., 2011, 2012a, 2012b, 2013; Viveiros et al., 2014 , 2015), and MultiGAS for the bulk composition of fumaroles and plumes (Aiuppa et al., 2007a, 2007b; Allard et al., 2014) , the observation of heat fluxes is much less developed. Thermal infrared images have been used with partial success to map the heat fluxes of sub fumarolic zones (Yuhara et al., 1978; Harris et al., 2009; Gaudin et al., 2013, 2016; Vilardo et al., 2015), but quantitative estimations are usually asso ciated to large uncertainties.

Being at the same time cheap and reliable, ground temperature re mains the most widely used technique for thermal monitoring (Peltier et al., 2012; Ricci et al., 2015). Measurements must be performed in the shallowest tens of centimeters of sub fumarolic zones in order to avoid the "buffer effect" of the steam, occurring when steam at saturat ing pressure coexists with liquid water, thus forcing the temperature to remain close to water boiling temperature (Ricci et al., 2015). At shallow depths, ground temperature is highly sensitive to atmospheric condi tions, in particular daily and seasonal temperature variations and rain falls (Peltier et al., 2012; Gaudin et al., 2015; Ricci et al., 2015). These atmospheric effects create superimposed signals that have to be filtered. Thus, discriminating these superficial effects from the deep modifica tions of the fluid circulation is a crucial challenge for a reliable thermal monitoring.

Several filtering methods based on the use of vertical profiles of ther mocouples have been proposed. The first one consists in averaging the temperature over $24 \mathrm{~h}$ and computing the vertical temperature gradi ent. More recently, Ricci et al. (2015) proposed to compute the coeffi cient of determination $\left(R^{2}\right)$ between the depth and the measured temperature, allowing distinguishing convective and conductive re gimes in the ground. This easy to use method is quite efficient to filter the conductive effects of seasonal and diurnal temperature variations from those due to changes in the geothermal heat flux, but i) it does not allow a quantification of the geothermal flux and ii) it does not take into account the disruption produced by the largest rainfalls that may occur on tropical volcanoes, thus severely limiting the range of use of these techniques at these latitudes.

To overcome these limitations, we propose here a new methodology based on the estimation of the upward heat flux (UHF method) in the ground from vertical pairs of thermocouples. For the cases where the rainfalls affect significantly the soil temperature, we propose a further processing step integrating the precipitations in the energy balance, based on the study by Gaudin et al. (2015) and the computation of ex cess of total heat (ETH method) released by the ground, compared to a reference period. We test these methods against the gradient and the $\mathrm{R}^{2}$ techniques in two different contexts: 1) La Fossa di Vulcano (Italy), where precipitations are usually weak and have no visible effect on the soil temperatures; and 2) La Soufrière de Guadeloupe (French Lesser Antilles) where rainfalls play a significant role on the shallow heat and water circulation.

\section{Vertical structure of sub-fumarolic areas}

Sub fumarolic areas are zones characterized by anomalous temper atures due to the rise of steam at the vicinity of the surface. Their ther mal behavior is controlled by the interaction of two factors: 1) the geothermal flux, corresponding to the heat flux carried by the steam ris ing from depth and 2) the atmosphere, which is cooling down the most superficial layers, leading to condensation of most of the steam in the ground.

Temperature measurements in a steady state allow describing the vertical structure of sub fumarolic areas in three successive zones (Aubert, 1999; Gaudin et al., 2013; Ricci et al., 2015). In the deepest zone (convective zone, see Fig. 1), the temperature remains constant and close to the water boiling temperature, and heat is mainly carried by the convection of water. This constant temperature due to the buffer ing effect of steam makes this zone strongly unsuitable for monitoring of hydrothermal activity (Ricci et al., 2015). When approaching the sur face, the cooling effect of the atmosphere provokes the condensation of the steam (condensation zone, see Fig. 1). The resulting condensed water flows downward in the condensation zone. Meanwhile, the

\section{LOW FLUX \\ HIGH FLUX}

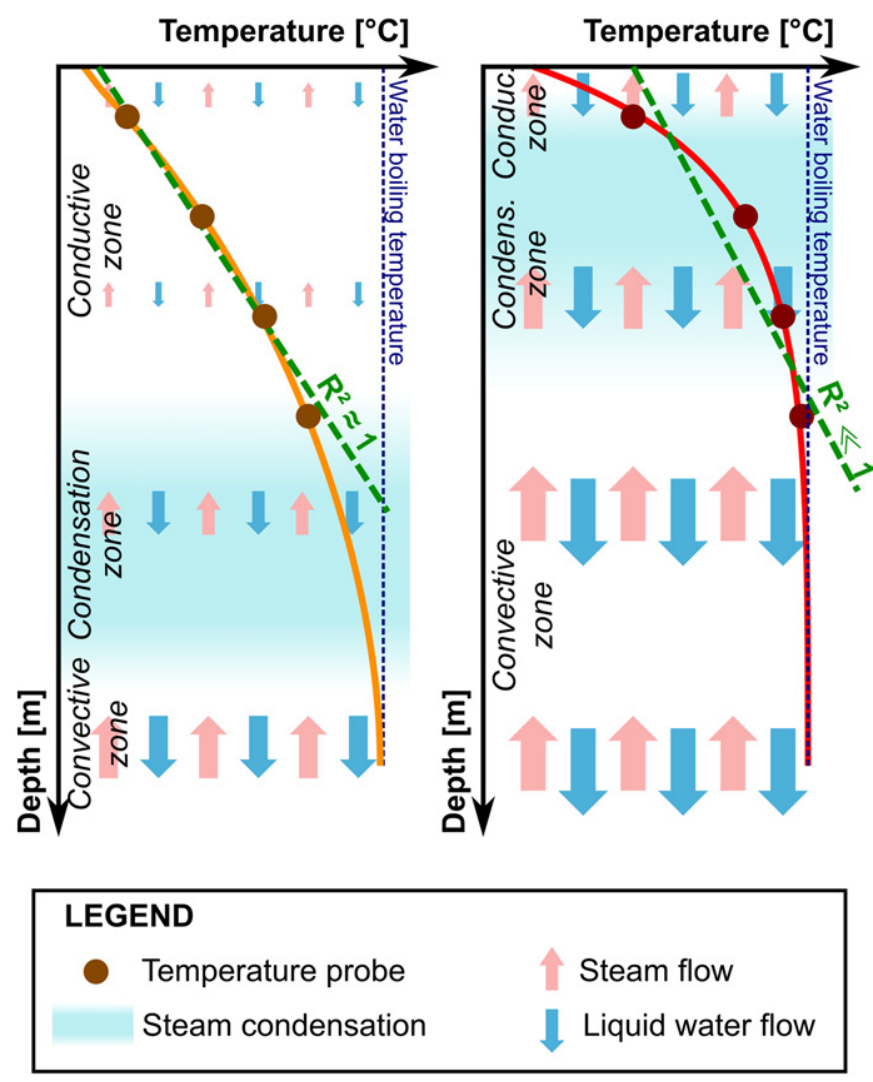

Fig 1. Principle of the method of the coefficient of determination ( $R^{2}$, Ricci et al, 2015) for the thermal monitoring of sub-fumarolic areas. The temperature gradient is determined by the conductive heat flux, following Fourier law. In the convective zone, where no conduction occurs, the gradient is null, while in the conductive zone where the amount of steam is negligible, it is constant. If all the thermometers are located in the conductive zone (left panel) where temperature evolution versus depth is almost linear, the coefficient of determination $\mathrm{R}^{2}$ is close to one. If the heat flux increases (right panel), the condensation zone shallows, and the deepest temperatures are no longer aligned, thus reducing the value of $\mathrm{R}^{2}$ 
temperature gradient induces conductive heat transfer, which increases moving upward while the steam content decreases. The most superfi cial zone (conductive zone, see Fig. 1) exhibits a quasi linear tempera ture decay. Indeed, the steam content is low, and most of the heat is carried by conduction. The limits between these three zones are not precisely defined, but rather smooth transitions can be identified.

When the geothermal steam flux increases, the cooling effect of the atmosphere is more limited. Thus, the condensation level rises, and the conductive zone becomes thinner and exhibits a higher thermal gradi ent. For the highest fluxes $\left(\approx 500 \mathrm{~W} / \mathrm{m}^{2}\right)$, a significant proportion of the condensation takes place in the atmosphere, and the conductive zone disappears (Gaudin et al., 2013) turning the sub fumarolic area into a fumarolic one.

\section{Techniques of sub-fumarolic areas thermal monitoring}

\subsection{Raw temperature}

Raw temperature in the convective zone has been widely used to map and detect changes due to the disruptions of geothermal flux in sub fumarolic areas. Indeed, both surface temperature and temperature gradient in the conductive zone are linked to the geothermal flux. How ever, being also influenced by atmospheric temperatures, variations of the raw temperature are usually difficult to interpret. Daily variations of temperature can be filtered by averaging the data on $24 \mathrm{~h}$, but season al variations are necessarily visible in the time series.

\subsection{Temperature gradient}

Unlike the raw temperature, the vertical temperature gradient in a steady state in the conductive zone does not rely on the atmospheric temperature, but only on the geothermal flux $\Phi_{\text {cond }}$ according to Fourier law:

$\frac{T_{2}-T_{1}}{z_{2}-z_{1}} \quad \Phi_{\text {cond }} / k$

where $T_{1}$ and $T_{2}$ represent the temperatures at depths $z_{1}$ and $z_{2}$, respec tively. The thermal conductivity of the ground $k$ is a characteristic of the ground itself, and we assume that it remains constant with time and space (Gaudin et al., 2015). Thus, in the conductive zone, provided the convective flux remains negligible, the temperature gradient is directly representative of the geothermal flux.

\subsection{Coefficient of determination $\left(R^{2}\right)$ method}

The coefficient of determination $\left(\mathrm{R}^{2}\right)$ method, first described in Ricci et al. (2015), is based on the linear increase of temperatures with depth in the conductive zone (Fig. 1). It consists in computing the coefficient of determination $\left(\mathrm{R}^{2}\right)$ of the depth on the temperature measured by a ver tical series of thermometers:

$R^{2} \frac{\left[\sum\left(T_{i}-\bar{T}\right)\left(z_{i}-\bar{z}\right)\right]^{2}}{\sum\left(T_{i}-\bar{T}\right)^{2} \sum\left(z_{i}-\bar{z}\right)^{2}}$

where $\bar{x}$ is the mean depth of the thermometers, and $\bar{T}$ is the average of the temperatures $T_{i}$ measured by the thermometers at a given time. If all thermometers are located in the conductive zone, the temperature gra dient is constant, and $\mathrm{R}^{2}$ is close to 1 (Fig. 1, left). Conversely, for higher fluxes, when the deepest thermometers are in the condensation or the convection zone, the relationship between depth and temperature is no longer linear, and $\mathrm{R}^{2}$ decreases (Fig. 1, right). With respect to the temperature gradient, this empirical method is less sensitive to daily and seasonal temperature variations (Ricci et al., 2015).

\subsection{Upward heat flux (UHF) method}

Though simple, the above mentioned methods strongly rely on the thermometer position in the ground with respects to the conduction, the condensation or the convection zones. In addition, being empirical, they prevent from quantitative analysis and uncertainties estimations. To overcome these issues, we propose a new method based on the esti mation of the upward heat flux UHF between two successive thermom eters (Aubert, 1999; Gaudin et al., 2015).

The upward heat flux is defined as the sum of the conductive $\Phi_{\text {cond }}$ and the convective $\Phi_{\text {conv }}$ components (Fig. 2a):

$\mathrm{UHF} \Phi_{\text {cond }}+\Phi_{\text {conv }}$

The conductive flux $\Phi_{\text {cond }}$ can be estimated through Fourier law as:

$\Phi_{\text {cond }} k\left(T_{2}-T_{1}\right) /\left(z_{2}-z_{1}\right)$

where $T_{1}$ and $T_{2}$ are the temperatures measured at the depths $z_{1}$ and $z_{2}$, and $k$ is the thermal conductivity of the ground, depending on the soil nature and porosity (Robertson, 1988; Brigaud and Vasseur, 1989), but usually close to $1 \mathrm{~W} \mathrm{~m}^{-1} \mathrm{~K}^{-1}$ (Robertson, 1988; Chiodini et al., 2005; Gaudin et al., 2015).

In order to estimate the heat flux carried by the steam convection $\Phi_{\text {conv }}$, we assume a constant permeability and, consequently a constant rise velocity of the steam in the column (Gaudin et al., 2013). Under this hypothesis, the proportion of heat transported by convection depends on the steam content inside the rock pores, which can be computed through the Rankine formula (Pruppacher and Klett, 2000). Once con densed, water percolates so that an equivalent amount of liquid water flows downwards (Gaudin et al., 2015). Following Gaudin et al. (2015), we use the following formula to estimate $\Phi_{\text {conv }}$ :

$\Phi_{\text {conv }} \quad \Phi_{\text {cond }} /\left[\left(\frac{L+\left(c_{v}-c_{w}\right)\left(T_{b o}-T_{a t m}\right)}{L+\left(c_{v}-c_{w}\right)\left(T-T_{a t m}\right)} \exp \left(\frac{5120}{T}-\frac{5120}{T_{b o}}\right)\right) \quad 1\right]$ (5)

where $T_{b o}$ and $T_{a t m}$ are respectively the boiling temperature of water and the atmospheric temperature, $T$ the soil temperature, computed as the mean of $T_{1}$ and $T_{2}, c_{v}$ and $c_{w}$ the heat capacities of steam (1.99 $\left.\times 10^{3} \mathrm{~J} \mathrm{~kg}^{-1} \mathrm{~K}^{-1}\right)$ and water $\left(4.18 \times 10^{3} \mathrm{~J} \mathrm{~kg}^{-1} \mathrm{~K}^{-1}\right)$, and $L$ the enthalpy of vaporization of water $\left(2.35 \times 10^{6} \mathrm{~J} \mathrm{~kg}^{-1}\right)$. For convenience, since the heat capacities of steam and water are significantly smaller than the en thalpy of vaporization, Eq. (5) may be simplified, with an error smaller than $8 \%$, as:

$\Phi_{\text {conv }} \approx \Phi_{\text {cond }} /\left[\exp \left(\frac{5120}{T}-\frac{5120}{T_{b o}}\right)-1\right]$

The sum of $\Phi_{\text {cond }}$ and $\Phi_{\text {conv }}$ gives the upward heat flux between the two thermometers.

\subsection{Excess of total heat (ETH) method}

The methods described above are based on the assumption that the heat flux is constant on a vertical profile, and representative of the geo thermal flux, i.e. that the ground temperature is in a steady state (Fig. $2 \mathrm{a})$. Yet, precipitations may significantly cool down the soil and alter the observed UHF, making these methods inefficient. Indeed, during precipitations, energy is transferred from the ground to heat up the per colating water, which decreases the ground temperature (Fig. 2b; Gaudin et al., 2015). In a second step, after the precipitation event, a fraction of the geothermal flux is used to reheat the soil and thus does not reach the surface (Fig. 2c) creating an apparent drop in the UHF (middle panel of Fig. 2). In other words, during rainfall events, the ground incurs an energy debt to heat up the percolating rainwater (i.e. the effective precipitations). This heat debt is gradually paid by levying heat from the geothermal flux. 


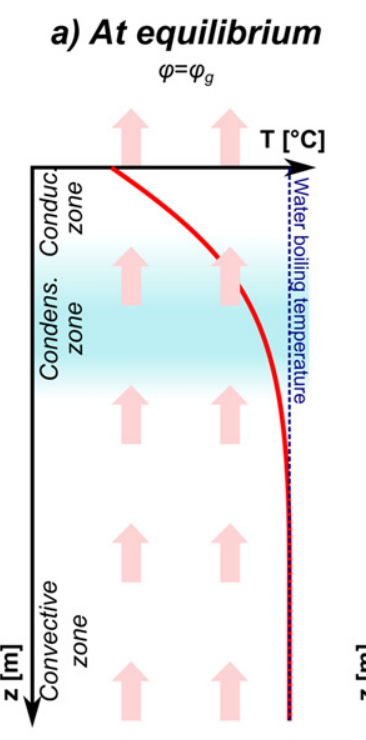

b) Rainfall event

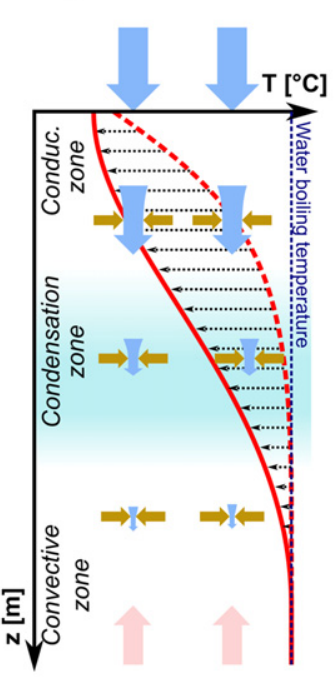

c) Recovery

$\varphi<\varphi_{g}$
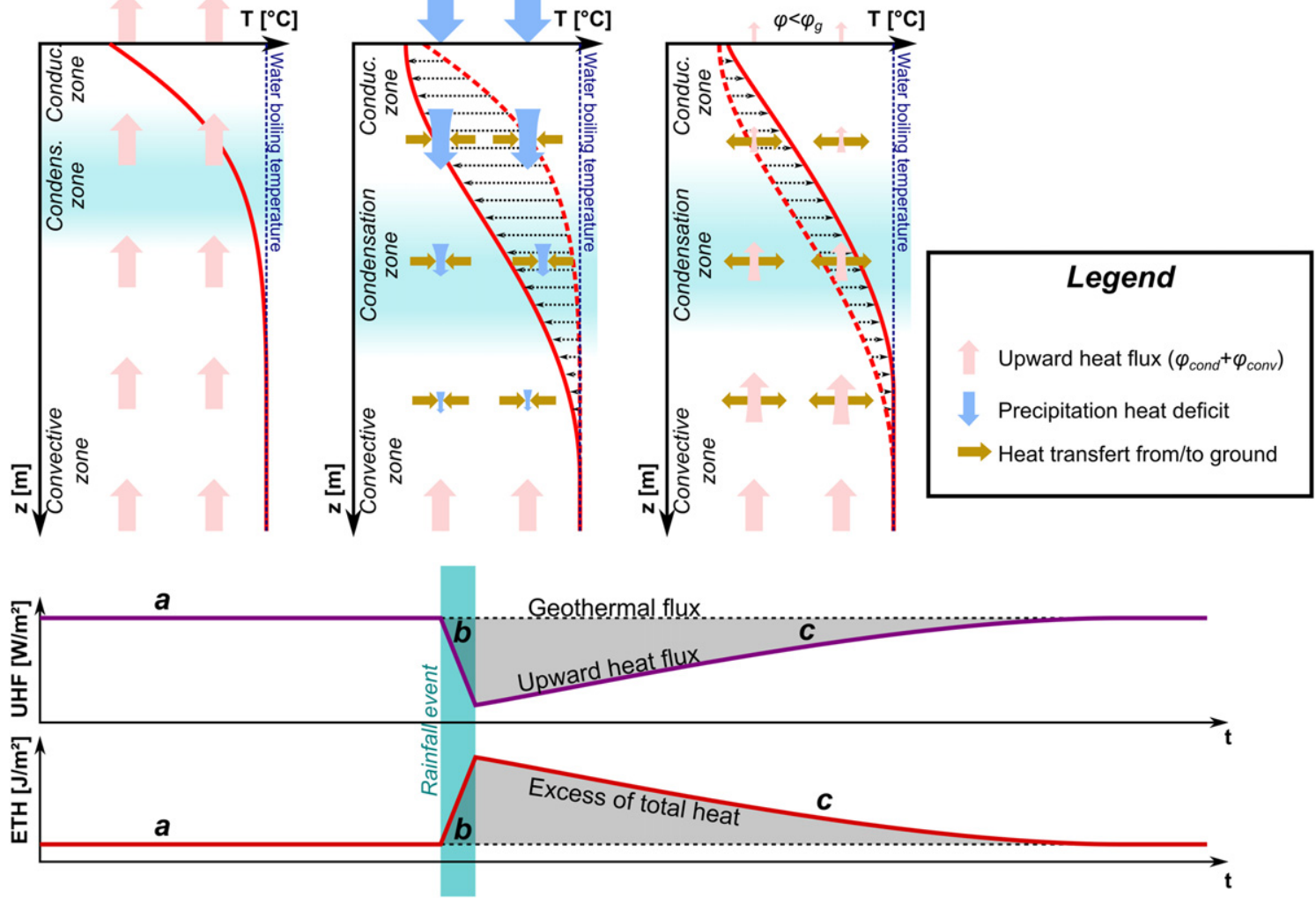

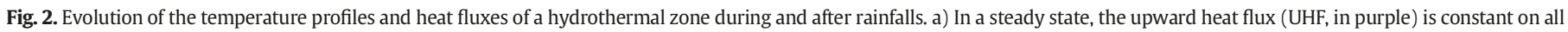

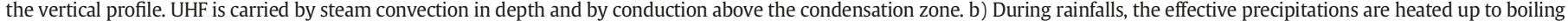

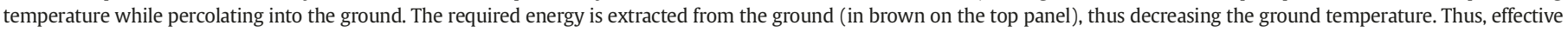

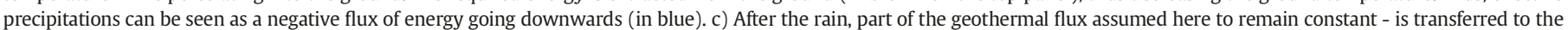

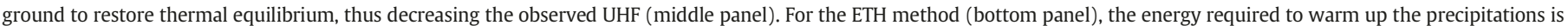
added to the balance at the time of the precipitations, thus creating a peak during the rainfalls. The anomaly progressively vanishes as the equilibrium is restored.

Consequently, the levied heat flux has to be added to the upward heat flux (UHF) to retrieve the total geothermal flux. Gaudin et al. (2015) demonstrated that the total heat debt of the soil corresponds to the energy that has been used to heat up the precipitations from the atmosphere temperature $T_{a t m}$ up to the boiling temperature $T_{b o}$, i.e.:

$\Delta E_{\text {rain,surf }} \quad h \rho_{w} c_{w}\left(T_{b o}-T_{a t m}\right)$

$h$ being the height of effective precipitations, $\rho_{w}$ the water density $\left(10^{3} \mathrm{~kg} / \mathrm{m}^{3}\right)$, and $c_{w}$ the water specific enthalpy. Following the same reasoning, if we consider a point at a given depth in the ground instead of the surface, the energy that has to be subtracted to the geothermal flux is the energy required to heat up the percolating water from the ac tual ground temperature $T$ at this depth to boiling temperature, that is:

$\Delta E_{\text {rain }} \quad h \rho_{w} c_{w}\left(T_{b o}-T\right)$

Although estimating the total energy required to reheat the soil is quite straightforward, evaluating the proportion of geothermal flux ac tually levied at a given time is not trivial and requires complex numer ical models (Gaudin et al., 2015). Consequently, it is more convenient to think in terms of total energy instead of fluxes. Operatively, for each time step $\mathrm{d} t$ (i.e. the delay between two successive temperature mea surements), we sum the energy corresponding to the upward heat flux (UHF) and the energy debt incurred by the precipitations. In ab sence of perturbation, the cumulative total energy is a linear function of time. In order to highlight the perturbations of this curve, we remove the mean trend, i.e. the upward heat flux in a steady state. Finally, we define the excess of total heat ETH as:

$$
\text { ETH } \quad \Sigma_{0}{ }^{t}\left[\left(\mathrm{UHFd} t+\Delta E_{\text {rain }}\right)-\left(\mathrm{UHFd} t+\Delta E_{\text {rain }}\right)_{\text {ref }}\right]
$$

In absence of geothermal perturbation, ETH should remain at a base line level. However, the energy used to re heat the soil after the precip itations is taken into account at the time of the precipitations. Thus, during a precipitation, the ETH is expected to rise suddenly, and to grad ually return to the baseline (bottom panel of Fig. 2), highlighting the en ergy debt incurrence and repayment. Therefore, the variations of the ETH must be interpreted considering long timescales.

In the supplementary material, an Excel spreadsheet allows to com pute results from the four computing methods.

\section{Datasets}

In order to compare the five above mentioned techniques, we con sidered two hydrothermal areas, located in Vulcano Fossa (Italy) and La Soufrière de Guadeloupe (French Lesser Antilles), selected because of their very different thermal behavior due to different climate. Both volcanoes were equipped with a vertical series of thermometers and a rain gauge during several months. 


\subsection{La Fossa di Vulcano}

La Fossa cone (391 m a.s.l.) is located on Vulcano, the southernmost island of the Aeolian calc alkaline arc (Fig. 3a). Since at least its last eruption in 1888 1890, it hosts a permanent hydrothermal system, whose size and extent significantly varied with time (Chiodini et al., 1995; Harris and Maciejewski, 2000; Granieri et al., 2006; Harris et al., 2009; Federico et al., 2010; Paonita et al., 2013). Nowadays, the activity is mostly concentrated near the main crater (Harris et al., 2009, 2012), but smaller fumarolic areas also appear on the slopes of the volcano (Revil et al., 2008).

La Fossa tuff cone is constituted by five main stratigraphic succes sions whereof Punte Nere formation, the oldest one (5.5 $3.8 \mathrm{ka}$, De Astis et al., 2013), represents its lower portion (Dellino and La Volpe, 1997). Punte Nere crater is the north westernmost of the five craters presently displayed by La Fossa edifice and its products, ranging from latitic to trachytic, built up the primordial edifice of La Fossa through the occurrence of hydromagmatic and magmatic dilute pyroclastic den sity currents, fallout deposits, and a late stage characterized by effusive activity.

The Punte Nere monitoring station, (PN, Fig. 3a) located on a struc tural limit, displays low thermal anomalies $\left(35^{\circ} \mathrm{C}\right.$ at a depth of $30 \mathrm{~cm}$, Barde Cabusson et al., 2009) and diffuse $\mathrm{CO}_{2}$ degassing (200 $\mathrm{g} \mathrm{m}^{-2}$ day $^{-1}$ between crisis and up to $2000 \mathrm{~g} \mathrm{~m}^{-2}$ day $^{-1}$ during crisis, Granieri et al., 2006). Being far from the main hydrothermal area and the high temperature fumaroles (600 $\mathrm{m}$ from the currently ac tive crater), this site is ideal for monitoring since it allows avoiding the buffer effect due to steam in zones where heat flux is too high. A series of four PT1000 thermocouples (accuracy of $0.2{ }^{\circ} \mathrm{C}$ ) were installed in the same hole (Fig. 4a) at depths of 10,30,50 and $70 \mathrm{~cm}$ (see Supplemen tary material Ricci et al., 2015). The hole was then filled back, and the measurements were hourly digitalized from May 12, 2009 to May 1, 2012. We point out that the first part of the dataset (up to July 28 , 2010) has been previously studied in Ricci et al. (2015) and revealed an increase of the fumarolic activity concomitant to the 2009 seismic crisis. This crisis can be interpreted as a weak unrest involving only the shallowest portions of the hydrothermal systems of La Fossa cone. The main elements characterizing these unrest phases are low increases of both temperature and flux of fumarolic fluids, widening of fumarolic fields and chemical changes indicative of an increasing input of mag matic fluids from a stationary magma body in concomitance with in creases of the local shallow seismicity.

In order to get a better overview of the fumarolic activity, we also used for comparison data from other instruments of the volcano perma nent network (Fig. 3a): i) a rain gauge providing hourly measurements, located in open air at the harbor, about $1000 \mathrm{~m}$ from the PN tempera ture station (database Istituto Nazionale di Geofisica e Vulcanologia, Sezione di Palermo, courtesy of Paolo Madonia); ii) a seismic station maintained by the INGV from which the daily number of seismic events can be counted (Cannata et al., 2012); iii) a UV scanning DOAS MARK1 allowing daily estimations of the total $\mathrm{SO}_{2}$ flux from the volcano (see an extended description in Vita et al., 2012); and iv) a WEST Systems $\mathrm{CO}_{2}$ flux meter with an automated accumulation chamber providing daily estimate of the diffuse $\mathrm{CO}_{2}$ flux at the summit area (see an extend ed description in Inguaggiato et al., 2012b) coupled with an open air thermometer. Note that the geochemical data were not corrected from the atmospheric conditions that may influence the observations (Viveiros et al., 2008), and that the reported seismic data represent the daily number of events and short lived interruptions may have caused some values underestimations.

\subsection{La Soufrière de Guadeloupe}

La Soufrière de Guadeloupe (1467 m a.s.l.) is a $300 \mathrm{~m}$ high dome lo cated at the south of Basse Terre Island in the Lesser Antilles subduction arc (Fig. 3b). It has been set up in 1530 A.D. (Boudon et al., 2008), and since then, has experienced six phreatic crises (Komorowski et al., 2008). Its complex geology, with radial fractures, massive andesite blocks and conglomerates formed during the phreatic explosions, is re sponsible for the existence of many fumarolic zones at the summit and
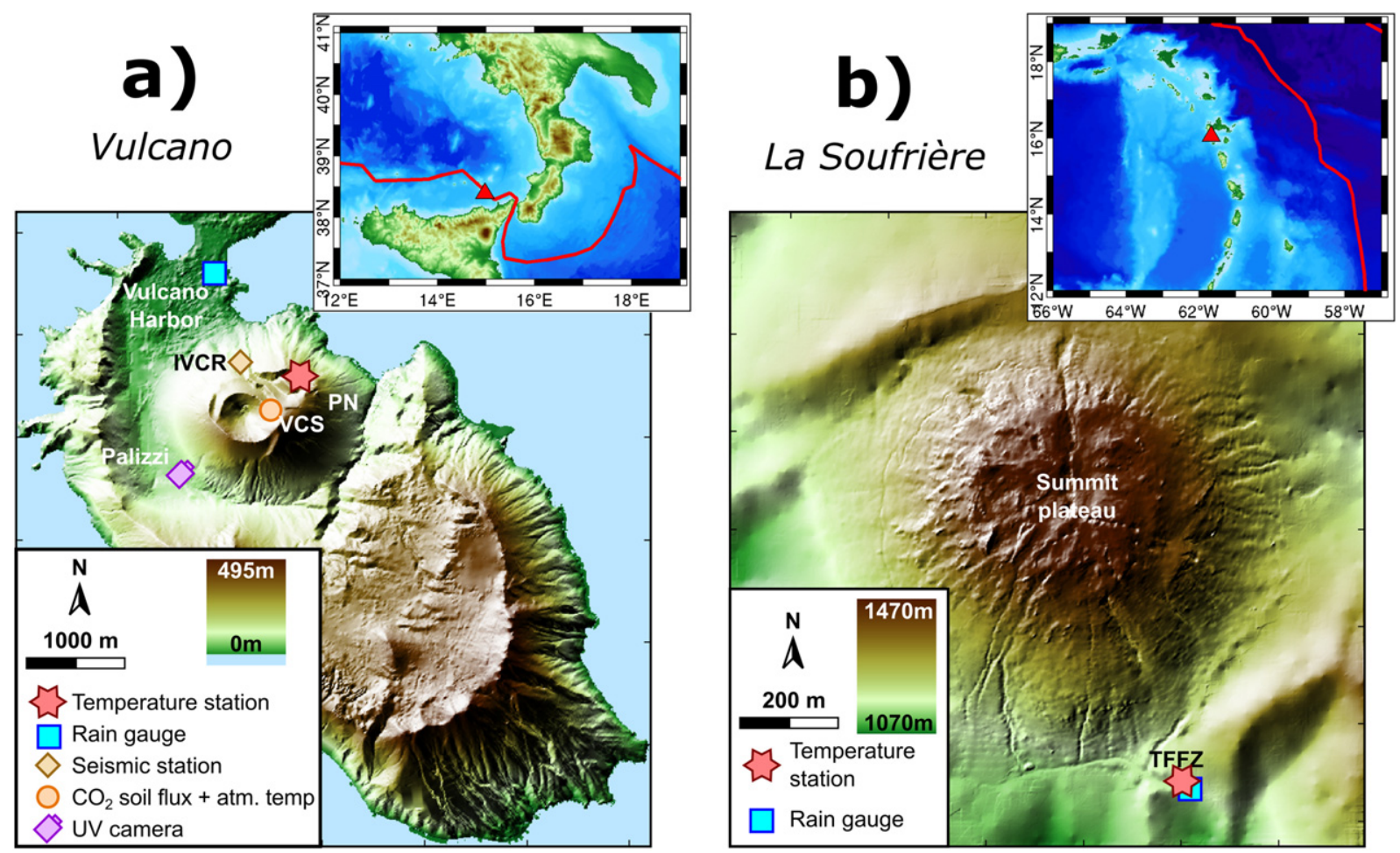

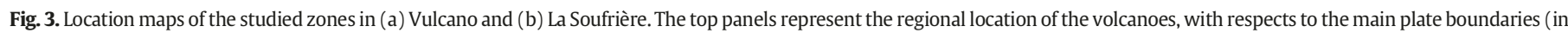
red). The bottom panels show the location of the different monitoring stations used in this study. 

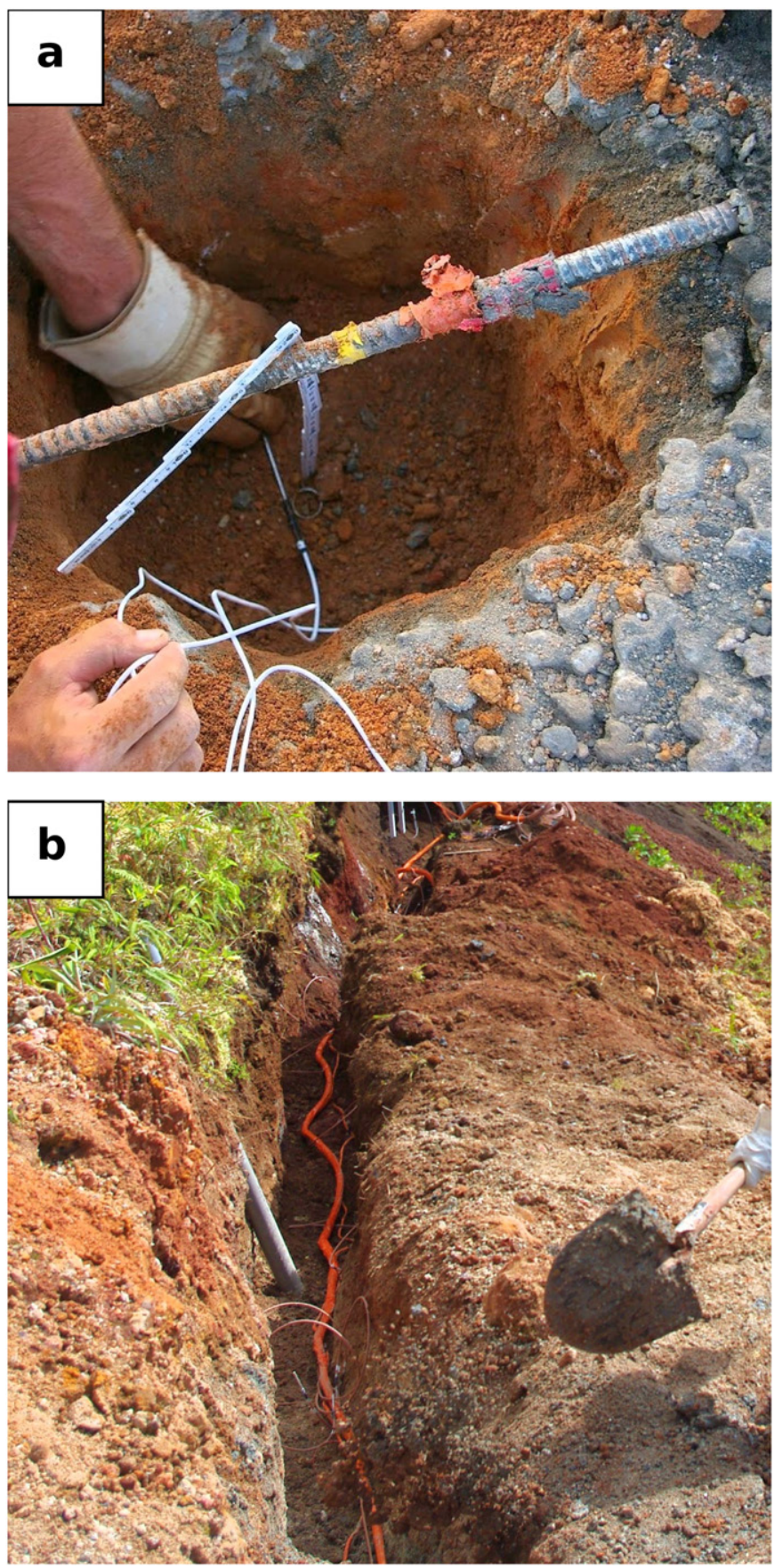

Fig. 4. Pictures of the installation of the setup at (a) Punte Nere (Vulcano) and (b) the Ty Fault fumarolic zone (La Soufrière de Guadeloupe).

at the base of the dome (Nicollin et al., 2006). Since the last phreatic cri sis, in 1976, the hydrothermal system is experiencing slow variations at timescales of tens of years. In particular, ongoing increase of the summit, activity and changes in hot spring water composition have been interpreted as the consequences of a magma intrusion in depth in 1992 (Villemant et al., 2014; OVSG IPGP, 2015). This geochemical crisis is associated to a seismic crisis starting in 1992 and peaking in 1998 with a 60 fold increase of the volcanic earthquakes (i.e. located $<2 \mathrm{~km}$ from the center of the dome at a depth $\leq 7 \mathrm{~km}$ ) compared to pre 1992 (Ucciani, 2015). In 2010, the time of the study, the average number of daily earthquakes was lower than 3, i.e. 58 more than the pre 1992 baseline level.

At the base of the dome, only the Ty Fault fumarolic zone (TFFZ, Fig. 3) has remained active since the last 1976 phreatic crisis (Gaudin et al.,
2013), despite a slow activity decrease due to argilization (Brothelande et al., 2014). At the time of the study, TFFZ was made of five thermal anomaly patches, each $\sim 30$ m wide (Gaudin et al., 2016) and was releas ing about $1 \mathrm{MW}$ of heat. Expelled gas is mainly water as demonstrated by the observed temperatures $\left(9495{ }^{\circ} \mathrm{C}\right.$ at a depth of $70 \mathrm{~cm}$; Allard et al., 1998; Gaudin et al., 2013), $\mathrm{CO}_{2}$ being the main component of the dry phase. In 2010, a permanent station was installed in a $0.6 \times 0.8$ $\times 31 \mathrm{~m}$ trench (Fig. 4b, Gaudin et al., 2015). This station included five vertical series of thermometers at 10,30,50 and $70 \mathrm{~cm}$ depth (Camp bell Scientific105E, precision of $0.5{ }^{\circ} \mathrm{C}$ ) located inside and at the border of the thermal anomaly. In addition, a Campbell Scientific ARG100 tip ping bucket gauge (measuring step of $0.25 \mathrm{~mm}$ ) was buried at $30 \mathrm{~cm}$ depth to measure the effective precipitations, i.e. the amount of rainfall effectively penetrating in the soil (see details in Gaudin et al. (2015)). The data were hourly digitized by a Campbell Scientific AM25T multi plexer, and stored in a Campbell Scientific CR1000 data logger from Jan uary 22, 2010 to July 23, 2010, when it was damaged by a landslide. Unlike at PN, the results at TFFZ appeared highly impacted by the rain falls, in particular at the boundary of the thermal anomaly zone (Gaudin et al., 2015). In this paper, we focus on the most peripheral vertical pro file (denoted point \#101 in Gaudin et al. (2015)) which is both the most complete dataset and the profile most impacted by rainfalls due to a low geothermal flux ( $130 \mathrm{~W} / \mathrm{m}^{2}$, Gaudin et al. (2015)). The results of the four other profiles described in Gaudin et al. (2015) are provided as Sup plemental material.

\section{Results}

\subsection{Punte Nere (Vulcano)}

Fig. 5 shows the multi disciplinary dataset recorded at PN during 1085 days between May 2009 and May 2012. On this period, $2605 \mathrm{~mm}$ of rain were recorded (Fig. 5a), representing an average of $2.40 \mathrm{~mm} /$ day. Seasonal effects are visible, with a rainfall peaks usually in September to February and relative dryness in May to July.

The four temperature gauges display some noticeable evolutions (Fig. 5b). At the scale of a few days, changes of $510{ }^{\circ} \mathrm{C}$ are visible with no direct relation with rainfalls. These variations are visible on the four thermometers with amplitude slightly decreasing with depth, except between November 2009 and January 2010, when the deepest thermometer remains around $95^{\circ} \mathrm{C}$. At the scale of months, tempera tures vary by $20{ }^{\circ} \mathrm{C}$ approx. Increase of the measured temperatures may be associated to either a seasonal effect or an increase of the heat flux. Therefore, although temperature peaks in winter (October 2009 January 2010 and November 2011) may be associated unambiguously to thermal crises, higher temperatures in spring and summer (black arrow on Fig. 5b) compared to winter (white arrow) could potentially be associated to seasonal effects.

Fig. $5 c$ to Fig. $5 \mathrm{f}$ represent the results of the four processing algo rithms tested in this study. The temperature gradient of the two shallowest pairs of thermometers (Fig. $5 \mathrm{c}$ ) is most of the time around $6070^{\circ} \mathrm{C} / \mathrm{m}$, but rises to 100 or higher in three distinct periods, denoted "A", "B" and "C". Conversely, the deepest pair displays an opposite be havior, probably because the temperature at $70 \mathrm{~cm}$ is buffered at around water boiling temperature while the shallower temperatures rise.

The coefficient of determination shows very clearly the " $\mathrm{A}$ " and " $\mathrm{B}$ " thermal crises, while the " $\mathrm{C}$ " event is practically undetectable (Fig. $5 d)$. Opposite to the temperature gradient technique, the onset and the end of the thermal crises look sharp. We note that no signal is de tectable if taking into account only the three shallowest thermometers (in green), because all of them remain in the conductive zone at all time.

The UHF results for these three pairs of thermocouples (Fig. 5e) are consistent among each other showing three simultaneous increases with a comparable intensity (except the pair $3050 \mathrm{~cm}$ at the beginning of the A period). All of them suggest three thermal crises but with 


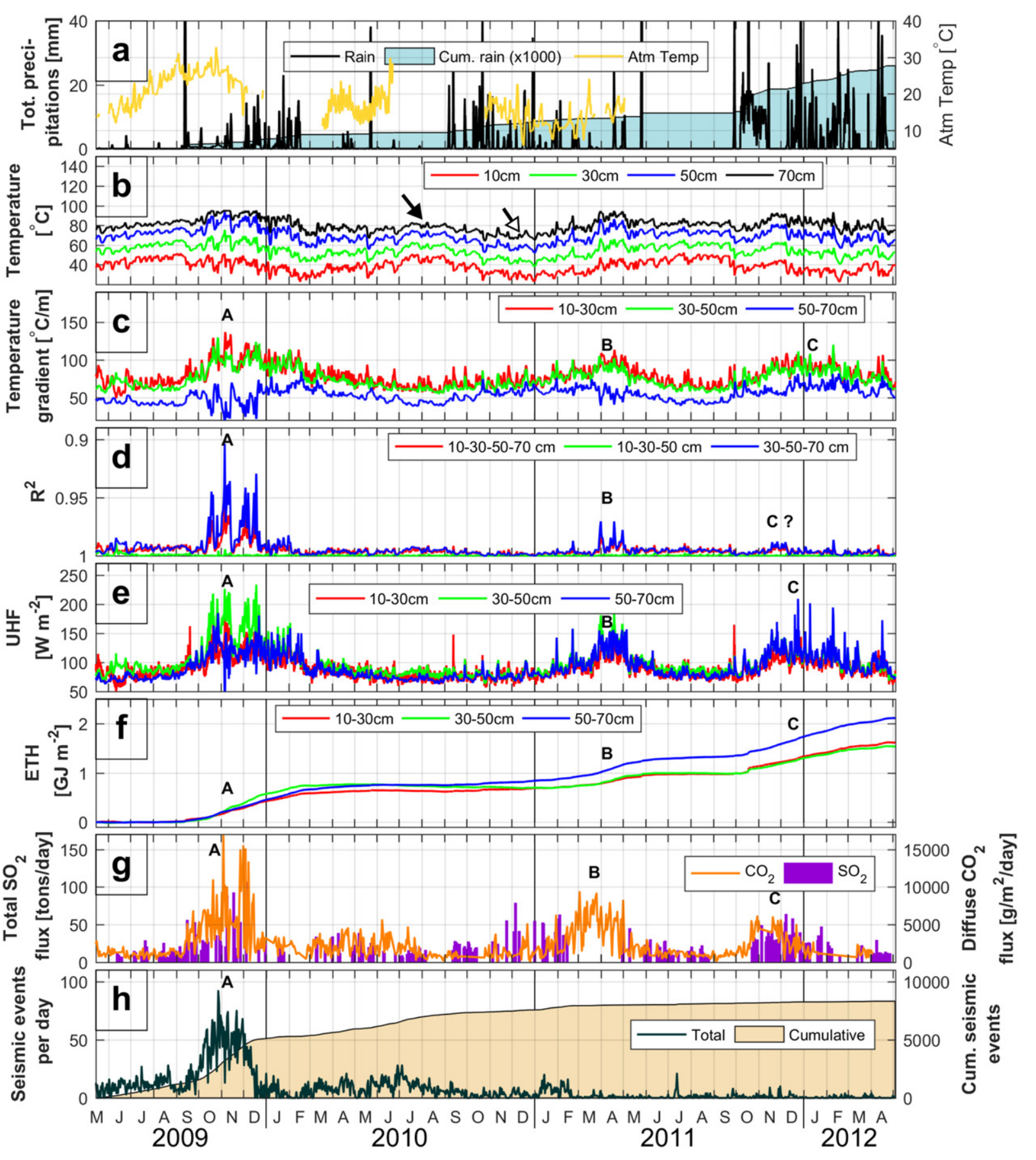

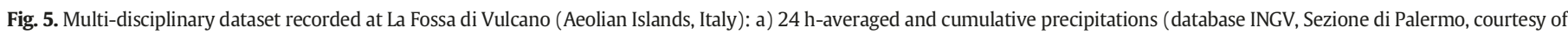

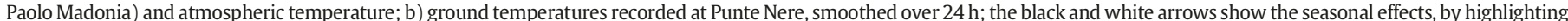

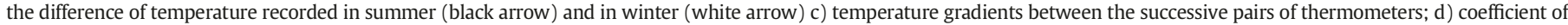

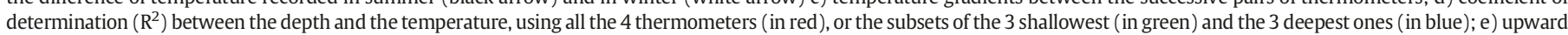

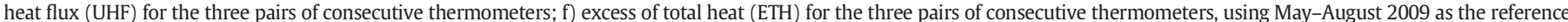
period; $\mathrm{g}$ ) $\mathrm{CO}_{2}$ (in orange) and $\mathrm{SO}_{2}$ (in purple) fluxes from the geochemical monitoring stations; h) number of seismic events recorded at IVCR station (see location on Fig. 3 ).

progressive onsets, and with a duration comparable to that highlighted by the gradient method (i.e. longer than suggested by the $\mathrm{R}^{2}$ method).

These thermal crises appear even better on the ETH curve (Fig. 5f), which allows to estimate the total excess of heat released by the three episodes: $0.50 .7 \mathrm{GJ} \mathrm{m}^{-2}, 0.20 .35 \mathrm{GJ} \mathrm{m}^{-2}$ and $0.30 .55 \mathrm{GJ} \mathrm{m}^{-2}$, re spectively. Note that, because precipitations are low, these values de pend very little on the proportion of rainfall percolating with respects to the total rainfall (for this figure, we considered that all the precipita tion percolates in the soil).
$\mathrm{CO}_{2}$ and $\mathrm{SO}_{2}$ measurements (Fig. $5 \mathrm{~g}$ ) show that each of the three thermal crises is associated to a geochemical crisis. A positive correla tion is clearly visible between the intensity of the $\mathrm{CO}_{2}$ output and the UHF. The "A" episode is also associated to a seismic crisis (Fig. 5h; Ricci et al., 2015) and/or increased magmatic input (Inguaggiato et al., 2012b).

In order to discriminate better the duration of the seismic, thermal, and geochemical crises, we plotted on the same graph the precipita tions, the $\mathrm{CO}_{2}$ flux, the thermal flux and the number of seismic events 
(Fig. 6). Each curve is normalized, using the mean value and the stan dard deviation of a reference period during which no thermal crisis was detected (June August 2009). On the bottom panel, we color coded each data to represent the normal periods (normalized index $<2$, in green) and the crises (normalized index $>10$, in red). For each case, the thermal crisis starts later than the geochemical one. In the "A" episode, the seismic crisis arise even later.

\subsection{Ty Fault Fumarolic Zone (La Soufrière)}

Unlike PN, the Ty Fault Fumarolic Zone (TFFZ) is much more affected by large tropical rains (Fig. 7a b), with a first event occurring on January 26, 2010 (300 mm), and almost continuous precipitations from April $(1000 \mathrm{~mm} / \mathrm{month}$ in average) to the end of the investigation period (end of July 2010). Temperature drops depend on the effective rainfalls (Gaudin et al., 2015) and can reach $70{ }^{\circ} \mathrm{C}$. The temperature gradient varies linearly with the temperature (Fig. 7c), with the noticeable ex ception of the pair $5070 \mathrm{~cm}$ (in blue) which are, most of the time, in the convective or the condensation zone.

The coefficient of determination $\left(R^{2}\right)$ exhibits clear peaks (Fig. $7 d$ ), but all of them are related to artifacts linked to instrumental malfunc tion (e.g. March 10, 2010) or rainfalls (e.g. January 26, 2010). The drop of the coefficient of determination after the rainfalls is due to the de crease of the temperature difference between the successive pairs of thermometers, enhancing the signal to noise ratio. However, we note that the coefficient of determination recovers to its reference value slightly faster than the temperature and the gradient. Similarly, the UHF is also strongly affected by the precipitations (Fig. 7e), highlighting again the need to take into account the precipitation in the thermal bal ance of the zone.

As expected, the ETH instantaneously rises each rainfall while it de creases slowly until a baseline after the rain event (Fig. 7f). These varia tions represent the "energy debt" contracted by the ground in order to heat the effective precipitations (Fig. 2, bottom panel). The debt is the progressively paid until the system reach the steady state. We note that the baseline is comprised between -0.4 and $-0.7 \mathrm{GJ} \mathrm{m}^{-2}$, indicat ing that the system was out of equilibrium at the start of the survey. Overall, apart from the oscillations associated to rainfalls, the ETH re mains very close to its steady state value, pointing an absence of major thermal crisis during the observation period.
Indeed, the record duration (6 months) is shorter than the timescale of the hydrothermal system evolution (tens of years), observable both in the seismic records (Ucciani, 2015) and the geochemical composition activity of the hot springs and fumaroles (Villemant et al., 2014).

\section{Discussion}

\subsection{Performances of the processing techniques}

Our study allows comparing the performances of the four processing techniques (gradient, $\mathrm{R}^{2}$, UHF and ETH) in two very different contexts. On one hand, the Punte Nere dataset (Fig. 5) is representative of a dry environment, where the precipitations do not affect significantly the thermal behavior of the zone (absence of significant temperature drop after rainfalls), while at TFFZ, temperatures display a succession of cooling due to rainfalls and re heating phases, demonstrating that equi librium is rarely recovered. These two extreme cases may be distin guished by computing the ratio of the flux required to heat the precipitations up to $100{ }^{\circ} \mathrm{C}$ over the geothermal heat flux (Eq. (7)), de noted $1 / \alpha$ in Gaudin et al., 2015:

$1 / \alpha \quad h \rho_{w} c_{w}\left(T_{b o}-T_{a t m}\right) /(\Phi t)$

where $h$ is the height of precipitations during the time interval $t$, and $\Phi$ the geothermal heat flux. In Punte Nere $(2500 \mathrm{~mm}$ of rainfalls in 3 years and $\Phi=80 \mathrm{~W} / \mathrm{m}^{2}$ ), $1 / \alpha$ is low (around $11 \%$ ), while it reaches $80 \%$ at TFFZ ( $4500 \mathrm{~mm}$ of rain in 6 months and $\Phi=120 \mathrm{~W} / \mathrm{m}^{2}$ ). These values can be interpreted as the proportion of the signal lost due to the precip itation effects. They can be compared to the overall noise/signal ratio of the method. At Punte Nere, in absence of thermal crisis and precipita tions, the comparison of estimations from the three couples of thermo couples (Fig. 5E) suggests that the uncertainty of the method is around $25 \%$. The $1 / \alpha$ ratio being significantly lower, the effects of rainfalls can be neglected. Conversely, at TFFZ, where $80 \%$ of the geothermal heat is dis sipated in rainfall heating, the impact of precipitations cannot be ignored.

\subsubsection{Dry environments}

Because it is poorly influenced by the precipitations, the Punte Nere dataset (Fig. 5) is the simplest case. First, we note that all the four tech niques, in particular the $\mathrm{R}^{2}$, UHF and ETH, successfully remove the

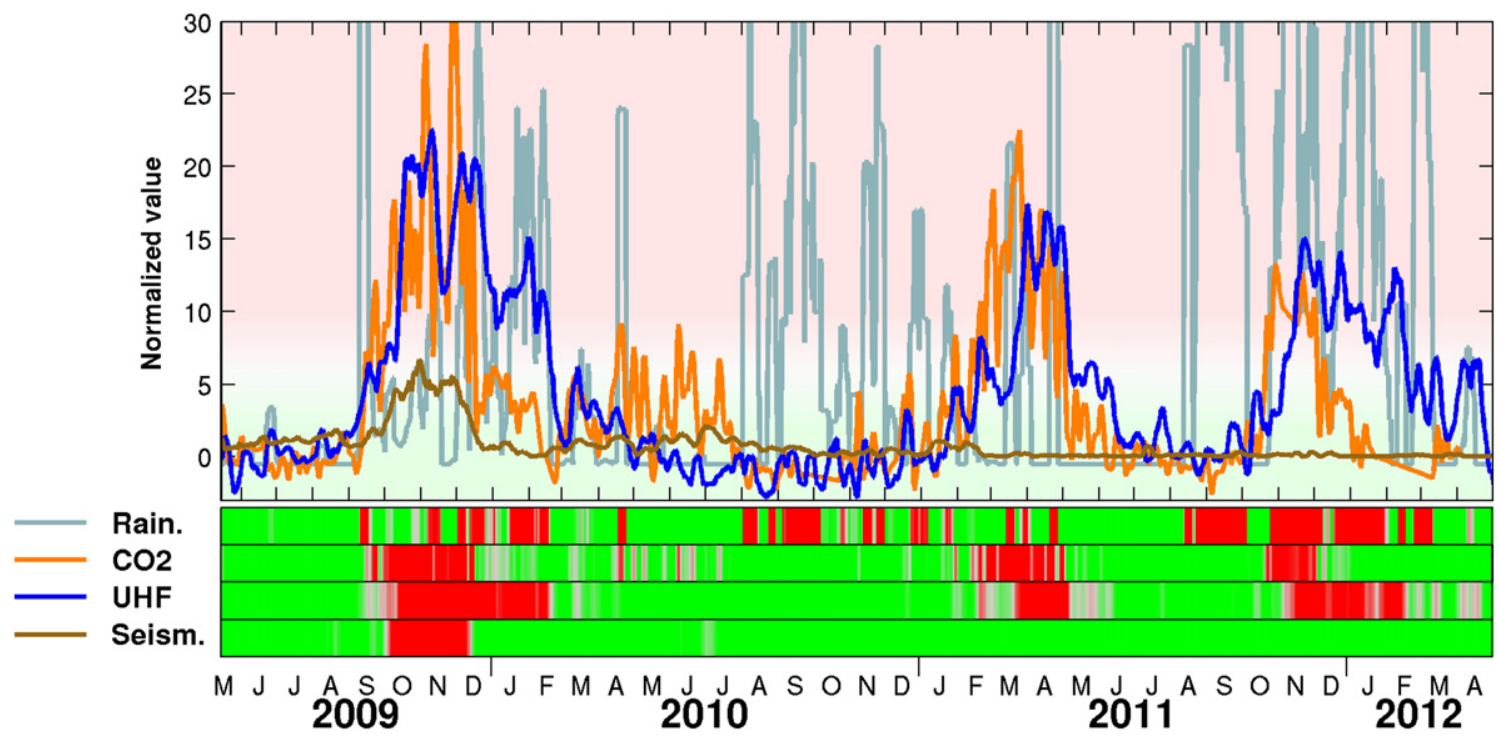

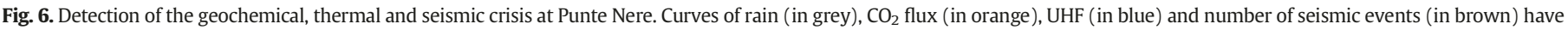

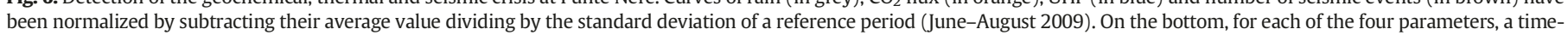
line shows the detected period of anomalies (in red, defined by an index $>10$ ) and the periods of rest (in green, defined by an index smaller than 2 ). 


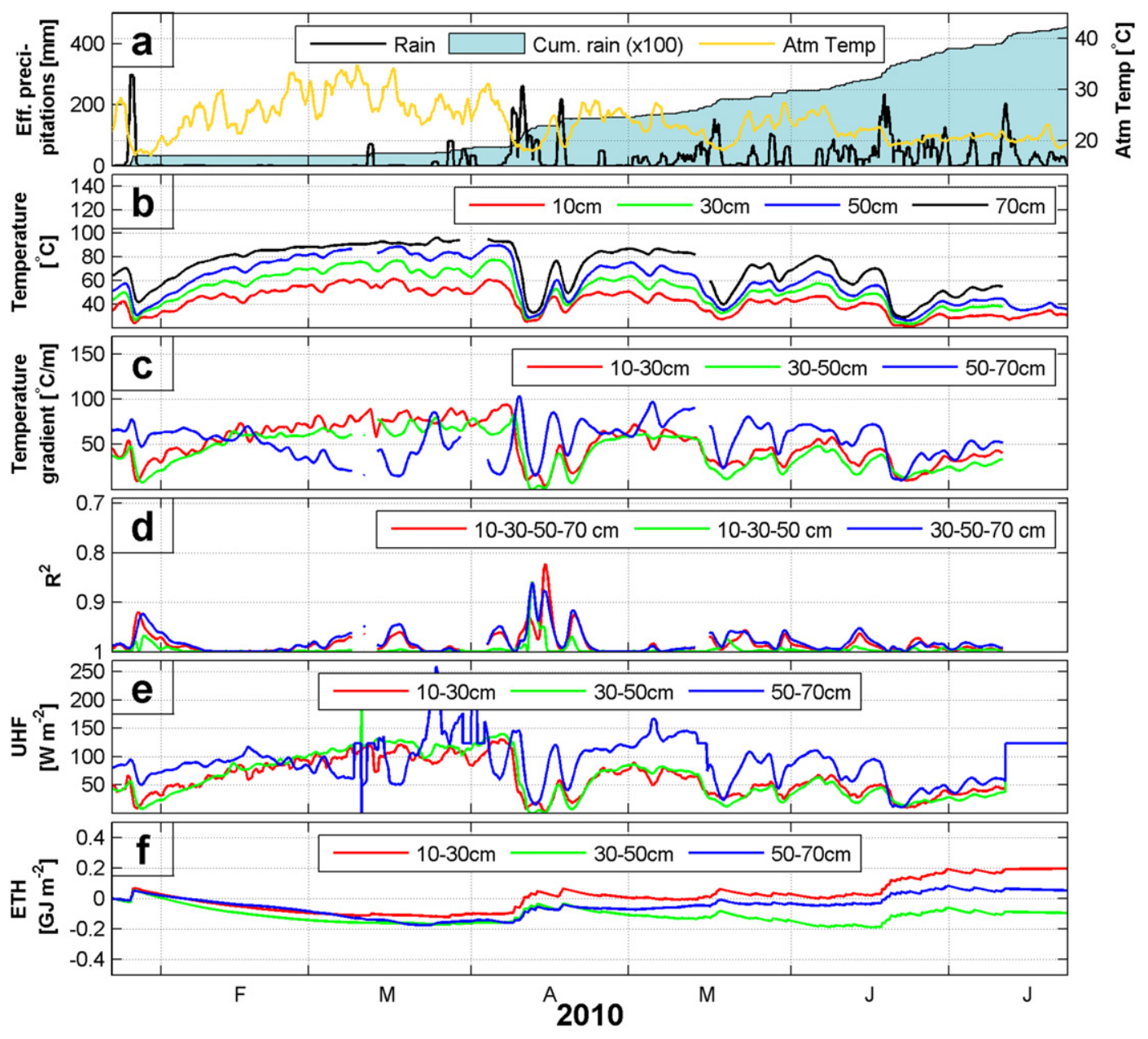

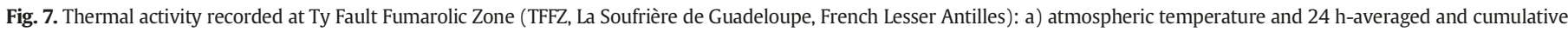

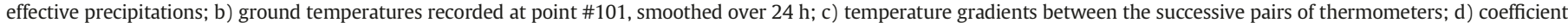

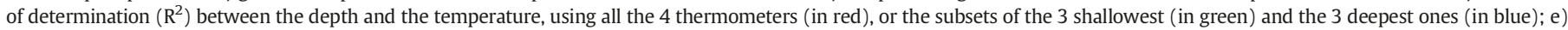

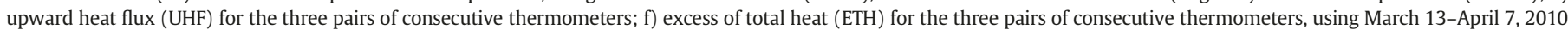
as the reference period.

seasonal component of the signal, which was the main limitation of using directly the temperature as monitoring system. In fact, the use of multiple thermometers allows computing temperature differences, thus not directly relying on the atmospheric temperature. Conversely, none of the methods removes the long term variations of the temperature.

The four methods agree to detect two thermal crises in autumn 2009 and spring 2011 (depicted "A" and "B" on Fig. 5). A third thermal crisis, in winter 2012 (depicted "C" on Fig. 5) is visible on the gradient, the UHF and the ETH graphs, but not detected with the coefficient of determina tion ( $\mathrm{R}^{2}$ method). In order to interpret this difference, we plotted the values of the $R^{2}$ against the UHF between the shallowest pair of thermo couples, for each point of the Punte Nere time series. Fig. 8 clearly dem onstrates that, for UHF below $120 \mathrm{~W} / \mathrm{m}^{2}, \mathrm{R}^{2}$ remains above 0.99 . At $120 \mathrm{~W} / \mathrm{m}^{2}$, we can estimate that the temperature of the deepest ther mometer is around $85{ }^{\circ} \mathrm{C}$ and the steam flux at that depth represents only $50 \%$ of the total flux (Gaudin et al., 2013). In other words, below this threshold whose value is specific to the setup all the thermome ters remain in the conductive zone. The coefficient of determination re mains close to 1 and exhibits no variation when the geothermal flux is changing. In such low flux zones, extra thermometers must be added to ensure that the deeper one is set in the convective zone, so that any variation of the flux will affect the coefficient of determination. Differ ently, for the gradient method, all the thermometers must be located in the conductive zone. This is illustrated in Figs. 5 and 7, where the
$70 \mathrm{~cm}$ thermometer often reached boiling temperature: the rise of the flux affects only the shallowest thermometers, and the temperature gra dient decreases, suggesting the absence of a crisis.

At first glance, the UHF method does not suffer from these limita tions, and allows getting quantitative estimates of the geothermal flux, provided a thermal gradient between the successive thermometers. However, quantitative estimates are subject to a correct estimation of the main parameters of the soil (thermal conductivity, heat capacity). In this study, we used values from the literature. Methods based on the penetration of the heat waves in the soil would enable to better con strain the thermal conductivity (Turcotte and Schubert, 2002) while the heat capacity of the soil and the proportion of precipitations percolating can be estimated by observing the temperature drop after rainfalls (Gaudin et al., 2015). The time integration of the UHF can provide an es timate of the total heat budget of the zone, which in turn then provides constraints on the minimum amount of magma that is cooling down in depth (Gaudin et al., 2016). Finally, we note that, unlike the other methods, the estimations for each pair of thermometers can be directly compared, thus increasing the reliability of the results.

\subsubsection{Wet environments}

TFFZ is representative of an extreme case where the rain significant ly affects the thermal behavior of sub fumarolic zones. The three methods that do not take into account the precipitations (gradient, $\mathrm{R}^{2}$ and UHF methods) are based on the assumption that the fluxes are in 


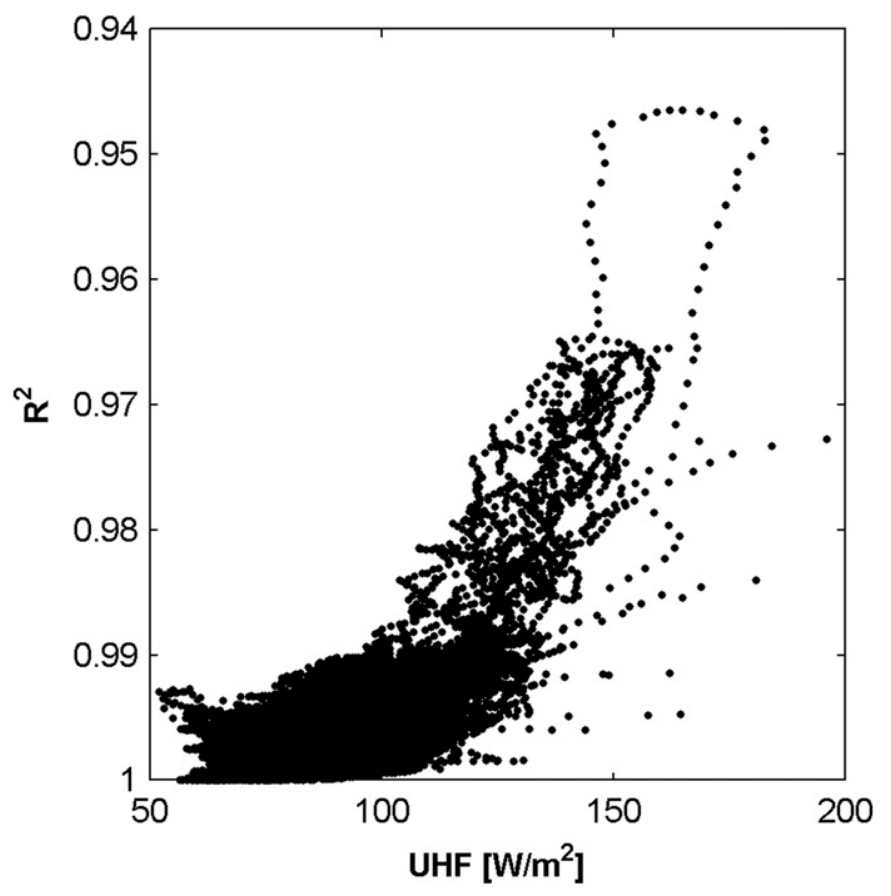

Fig. 8. Comparison between the upward heat flux (UHF) computed for the shallowest pairs of thermometers and the coefficient of determination $\left(\mathrm{R}^{2}\right)$ for the whole dataset of Punte Nere. For low UHF values $\left(<120 \mathrm{~W} / \mathrm{m}^{2}\right)$, the $\mathrm{R}^{2}$ remains at a constant values, and cannot be used to discriminate thermal anomalies. For higher values, a non-linear correlation is visible between $\mathrm{R}^{2}$ and $\mathrm{UHF}$.

a steady state. Consequently, these methods are valid only during a very limited time (a few days in March) and remain inefficient the rest of the time (Fig. 7c e). In that scope, the ETH method is a first attempt to inte grate the precipitations in the energy balance and to propose a continu ous monitoring tool for wet environments. However, large uncertainties can arise from (i) the definition of the baseline level of the geothermal flux and (ii) the assumptions on the rainfall model.

Integrating the heat flux with time to get the ETH allows avoiding the complex computation of the equilibrium restoring time (Gaudin et al., 2015). The first limitation of the ETH method is thus related to the definition of a reference baseline that may be a subjective choice. In the case of long time series, the average value of the total heat flux (i.e., UHF + effect of precipitations) can be considered, if the energy debt (in other words, the measured temperatures) is the same at the be ginning and at the end of the period. In the case of the TFFZ, where the duration of the survey was short, long term averaging was not possible, and we had to use the value of the heat flux at steady state as a refer ence. In order to assess the sensitivity of the ETH with respect to the choice of the reference period (March 13 to April 3) we split the latter in 5 sub periods of 4 days and computed the standard deviation of the estimated heat flux. Except for the deepest pair of thermometers (146 $\pm 58 \mathrm{~W} / \mathrm{m}^{2}$ ), the error in the estimate is limited to $20 \%$ (respectively $118 \pm 23$ and $130 \pm 14 \mathrm{~W} / \mathrm{m}^{2}$ respectively for the 1030 and the 30 $50 \mathrm{~cm}$ pairs; see also Supplementary material). These errors may gener ate a general linear trend that could be removed using longer time series.

The second limitation of the ETH method is the difficulty to estimate the effect of effective precipitations (note that this limitation applies to any geochemical flux monitoring (Viveiros et al., 2015)). The proportion of precipitation percolating in the soil might decrease with the intensity of the rainfall event, due to soil pores saturation. The use of a buried rain gauge in TFFZ allows measuring directly the effective precipitations, as suming that the soil response to precipitation is homogeneous in the TFFZ. A deeper analysis of the curves showed that the ratio between the effective precipitation at the rain gauge and the precipitation at the thermometer profiles ranges from 0.6 and 1 , with a value of 0.97 at point \#101 (Gaudin et al., 2015), bringing another 20\% uncertainties on the final result. On the other hand, although it is known to vary due to the deposition of minerals (in particular clay), ground permeability is assumed homogeneous horizontally. The validity of this assumption can be assessed directly by observing the consistency of the heat flux esti mation at different depths.

Due to these assumptions, ETH method is associated to relatively high uncertainties compared to UHF. In addition, the characteristic be havior of ETH curve after rainfalls (sharp increase during rainfalls followed by a slow return to baseline) prevents its use to detect short time changes of the geothermal flux. Consequently, only large fumarolic crises with an increase of the heat flux of at least $50 \%$ (ideally $100 \%$ ) over a few months may be detected. This limit corresponds approximately to the magnitude of the thermal crises observed at Vulcano. Unfortunately, the absence of fumarolic crisis at TFFZ during the six months of the ex periment did not allow a direct validation of the model.

Despite these limitations, ETH is so far the only thermal monitoring method in wet environments like La Soufrière de Guadeloupe, where the signal/noise ratio is around $20 \%$ (see Section 6.1). Longer reference periods for the definition of baseline activity level would allow reducing the uncertainties i.e. to increase the sensitivity of the method. More importantly, as for the UHF, the reliability of the method is strongly en hanced by using the comparison of the three pairs of thermometers to quantify the standard deviation of the measurements.

\subsection{Thermal flux and volcanic crises}

At Vulcano, the comparison between our UHF and the geochemical and seismic observations from the permanent monitoring network al lows to integrate the thermal crisis in the global interpretation of the volcanic crises. Based on the $\mathrm{R}^{2}$ technique, the " $\mathrm{A}$ " crisis was interpreted by Ricci et al. (2015) as a disruption of the hydrothermal system poten tially due to the seismic crisis that might have increased the pressure and/or the permeability inside the volcano edifice. Conversely, Inguaggiato et al., 2012b pointed an increased deep magmatic input that caused a disequilibrium of the large hydrothermal system located below the solfataric area (Federico et al., 2010).

The UHF technique allows describing the succession of events of the crises (Fig. 6). In the three cases, the heat flux starts increasing 2 to 10 days after the $\mathrm{CO}_{2}$ flux onset, and can last up to three times longer. In the " $\mathrm{A}$ " crisis, the seismic crisis starts 15 days after the $\mathrm{CO}_{2}$ flux onset and has a comparable duration. From a quantitative point of view, the " $\mathrm{A}$ " crisis has the largest intensity, both from a geochemical and a thermal point of view, followed by the "B" crisis and the " $\mathrm{C}$ " crisis. However, the increase of $\mathrm{CO}_{2}$ fluxes (multiplied respectively by $7.5,6$, and 4.5 in the "A", "B" and "C" crisis) and $\mathrm{SO}_{2}$ fluxes (multiplied respec tively by $5,3.5$, and 2.5 ) is much more important than the increase of the heat flux (multiplied by $1.85,1.65$, and 1.45 respectively). Opposite, the thermal crisis has the longest duration compared to the geochemical and the seismic one.

From these observations, we hypothesize that steam is released at depth simultaneously with magmatic gases. Steam might reach the sur face after the magmatic gases, because of the thermal inertia of the sys tem provoking condensation of steam at depth. The same thermal inertia may explain why the thermal crises appear more staggered (i.e., lasting longer with a smaller intensity) than the geochemical vari ations accompanying them.

The chronology of the events suggests that the seismic activity dur ing the " $\mathrm{A}$ " crisis is mainly a consequence of the enhancement of the hy drothermal circulation. This is supported by the earthquakes location ranging from 600 to $1200 \mathrm{~m}$ b.s.l (Ricci et al., 2015), i.e. between the magma bodies (1500 $2500 \mathrm{~m}$ b.s.l according to Nuccio and Paonita, 2001; Zanon et al., 2003) and the source of deformation located at sea level (Gambino and Guglielmino, 2008). The absence of seismic crisis during the " $\mathrm{B}$ " and " $\mathrm{C}$ " crisis might reveal that the paucity of fractures 
Comparison of the five thermal monitoring methods presented in this paper.

\begin{tabular}{|c|c|c|c|c|c|}
\hline & Raw temp. & Temp. gradient & $\mathrm{R}^{2}$ & UHF & ETH \\
\hline $\begin{array}{l}\text { References } \\
\text { Performances }\end{array}$ & - & - & (Ricci et al. (2015) & This study & This study \\
\hline Correction from atmospheric temperature variations & No & Partial & Yes & Yes & Yes \\
\hline Correction from rain & No & No & No & No & Yes \\
\hline Quantitative heat flux estimation & No & No & No & Yes & Yes \\
\hline \multicolumn{6}{|l|}{ Requirements } \\
\hline Minimum number of thermocouples & 1 & 2 & 3 & 2 & 2 \\
\hline Other time series & - & - & - & - & Precipitations \\
\hline Estimation of physical parameters of the soil & No & No & No & Yes & Yes \\
\hline
\end{tabular}

opening. The lower amount of released steam might have allowed reusing of existing steam paths.

The trigger of fumarolic crisis cannot be undoubtedly discriminate based on our observations. Crisis " $\mathrm{A}$ " and " $\mathrm{C}$ " follow large rainfalls (Fig. 6 ), suggesting that the percolation of meteoric water might also play a role by favoring steam production, crack opening and gas circulation. However, the "B" crisis and the rainfall in May 2011 demonstrate that this link, if existing, is not systematic. Another hypothesis is that the onset of the release of steam and magmatic gas might be associated to the emplacement of fresh magma.

\section{Conclusions}

The comparison between the raw temperature and the four process ing methods is summarized in Table 1. Compared to the other ones, our method based on the heat flux estimation (UHF method) is more com plex but presents large advantages. First, it can be used in quantitative energy balance of volcanoes. Moreover, it is less sensitive to a bad posi tioning of the thermocouples. Also, the same physical value is computed for several pairs of thermometers; the comparison of the flux estima tions at different depths allows estimating the uncertainties, making it by far the most robust method, which is highlighted by the fact that it successfully detected the three fumarolic crises at Vulcano. A further de velopment (ETH method) allows integrating data from rain gauges in order to remove the effects of large precipitations on the thermal behav ior of the zone. However, this method is associated to larger uncer tainties linked to (i) the estimation of the proportion of rainfall percolating in the soil and (ii) the choice of a reference period, and is therefore more difficult to interpret. Consequently, the UHF method should be favored in dry environments, and the ETH one used only in the zones affected by heavy precipitations where no other method can be operated.

The development of a processing method enabling the robust detec tion of increase of heat flux opens new perspectives both for monitoring and for the interpretation of fumarolic crises. Indeed, easy to install and cheap stations based on 4 thermometers are very reliable, since three independent values of the geothermal flux are measured at the same time and location, allowing discarding one or two malfunctioning ther mometers if necessary. In addition, the relative low cost of these stations compared to UV cameras or $\mathrm{CO}_{2}$ flux meter stations could allow increas ing dramatically the number of measurement locations around a volca no, thus providing a better resolved geographic information.

More importantly, our data on Vulcano demonstrates that, although detecting the same crises, heat and $\mathrm{CO}_{2}$ flux are complementary. The de layed, less intense, and longer thermal crises with respect to the geo chemical crises, points towards a buffer effect of the volcano that could be used to quantify the residence time of water in the edifice (Villemant et al., 2014) and better constrain circulation models.

\section{Acknowledgments}

The authors warmly thank the local assistance of the OVSG team for the data from La Soufrière, and the INGV Sezione di Palermo, for the
Database of Vulcano, courtesy of Paolo Madonia. Special thanks to Nicolas Crescenzo from Campbell Scientific France for his advices and technical support. This manuscript benefited from the careful proof reading of two anonymous reviewers and the editor A. Aiuppa, which greatly improved the contents. The research leading to these results has received funding from the ANR Domoscan, Programme Transverse en Recherches Volcanologiques (PTRV). This is the IPGP contribution number: 3819.

\section{Appendix A. Supplementary data}

The Excel spreadsheet can be used to compute and plot the temper ature gradient, coefficient of determination $\left(R^{2}\right)$, upward heat flux (UHF) and the excess of total heat (ETH) from temperature and rainfall time series. The TFFZ \#101 time series from La Soufrière de Guadeloupe are provided for example. (NB: only the values in italics are modifiable).

Figures $\mathrm{ms} 01$ to $\mathrm{ms} 04$ represent the thermal activity as computed by the four methods for the four other locations of the TFFZ described in Gaudin et al., 2015:

ms01 (point \#76m). due to a very high flux, all the measured tem perature remain close to boiling temperature, making it impossible to compute a temperature gradient and to retrieve fluxes.

ms02 (point \#82m): as previously, thermometers at $30 \mathrm{~cm}$ and below are at boiling temperature. Only the pair $1030 \mathrm{~cm}$ might be used. The ETH curve is displaying a slightly negative trend.

ms03 (point \#89m): the failure of the $10 \mathrm{~cm}$ thermometer prevents from the use of this profile (here again, 30,50 and $70 \mathrm{~cm}$ thermometers are close to boiling temperature).

ms04 (point \#94m): failure of the $30 \mathrm{~cm}$ thermometer makes the interpretation difficult. However, it is worth noticing that for the two pairs that are not saturated (10 30 and $3050 \mathrm{~cm}$ ), ETH remains very close to 0 .

\section{References}

Aiuppa, A., Inguaggiato, S., McGonigle, A.J.S., O'dwyer, M., Oppenheimer, C., Padgett, M.J., Rouwet, D., Valenza, M., 2005. H2S fluxes from Mt. Etna, Stromboli, and Vulcano (Italy) and implications for the sulfur budget at volcanoes. Geochim. Cosmochim. Acta 69 (7):1861-1871. http://dx.doi.org/10.1016/j.gca.2004.09.018.

Aiuppa, A., Moretti, R., Federico, C., Giudice, G., Gurrieri, S., Liuzzo, M., Papale, P., Shinohara, H., Valenza, M., 2007a. Forecasting Etna eruptions by real-time observation of volcanic gas composition. Geology 35:1115-1118. http://dx.doi.org/10.1130/ G24149A.1.

Aiuppa, A., Bagnato, E., Witt, M.LI., Mather, T.A., Parello, F., Pyle, D.M., Martin, R.S., 2007b. Real-time simultaneous detection of volcanic $\mathrm{Hg}$ and $\mathrm{SO} 2$ at La Fossa Crater, Vulcano (Aeolian Islands, Sicily). Geophys. Res. Lett. 34 (21).

Allard, P., Hammouya, G., Parello, F., 1998. Dégazage magmatique diffus à la Soufrière de Guadeloupe, Antilles. C. R. Acad. Sci. Ser. IIA Earth Planet. Sci. 327 (5), 315-318

Allard, P., Aiuppa, A., Beauducel, F., Gaudin, D., Di Napoli, R., Calabrese, C., Parello, F., Crispi, O., Hammouya, G., Tamburello, G., 2014. Steam and gas emission rate from La Soufriere volcano, Guadeloupe (Lesser Antilles): implications for the magmatic supply during degassing unrest. Chem. Geol. 384:76-93. http://dx.doi.org/10.1016/j. chemgeo.2014.06.019.

Aubert, M., 1999. Practical evaluation of steady heat discharge from dormant active volcanoes: case study of Vulcarolo fissure (Mount Etna, Italy). J. Volcanol. Geotherm. Res. 92:413-429. http://dx.doi.org/10.1016/S0377-0273(99)00088-8.

Barde-Cabusson, S., Finizola, A., Revil, A., Ricci, T., Piscitelli, S., Rizzo, E., Angeletti, B., Balasco, M., Bennati, L., Byrdina, S., Carzaniga, N., Crespy, A., Di Gangi, F., Morin, J., 
Perrone, A., Rossi, M., Roulleau, E., Suski, B., Villeneuve, N., 2009. New geological insights and structural control on fluid circulation in La Fossa cone (Vulcano, Aeolian Islands, Italy). J. Volcanol. Geotherm. Res. 185:231-245. http://dx.doi.org/10.1016/j. jvolgeores.2009.06.002.

Bertagnini, A., Landi, P., Santacroce, R., Sbrana, A., 1991. The 1906 eruption of Vesuvius: from magmatic to phreatomagmatic activity through the flashing of a shallow depth hydrothermal system. Bull. Volcanol. 53:517-532. http://dx.doi.org/10.1007/ BF00298153.

Boudon, G., Komorowski, J.-C., Villemant, B., Semet, M.P., 2008. A new scenario for the last magmatic eruption of La Soufrière of Guadeloupe (Lesser Antilles) in 1530 A.D. Evidence from stratigraphy radiocarbon dating and magmatic evolution of erupted products. J. Volcanol. Geotherm. Res. 178:474-490. http://dx.doi.org/10.1016/j. jvolgeores.2008.03.006 (Evaluating Explosive Eruption Risk at European Volcanoes Contribution from the EXPLORIS Project).

Brigaud, F., Vasseur, G., 1989. Mineralogy, porosity and fluid control on thermal conductivity of sedimentary rocks. Geophys. J. Int. 98:525-542. http://dx.doi.org/10.1111/j. 1365-246X.1989.tb02287.x.

Brothelande, E., Finizola, A., Peltier, A., Delcher, E., Komorowski, J.-C., Di Gangi, F. Borgogno, G., Passarella, M., Trovato, C., Legendre, Y., 2014. Fluid circulation pattern inside La Soufrière volcano (Guadeloupe) inferred from combined electrical resistivity tomography, self-potential, soil temperature and diffuse degassing measurements. J. Volcanol. Geotherm. Res. 288:105-122. http://dx.doi.org/10.1016/j.jvolgeores.2014. 10.007 .

Brown, G., Rymer, H., Dowden, J., Kapadia, P., Stevenson, D., Barquero, J., Morales, L.D. 1989. Energy budget analysis for Poás crater lake: implications for predicting volcanic activity. Nature 339:370-373. http://dx.doi.org/10.1038/339370a0.

Cannata, A., Diliberto, S., Alparone, S., Gambino, S., Gresta, S., Liotta, M., Madonia, P., Milluzzo, V., Aliotta, M., Montalto, P., 2012. Multiparametric approach in investigating volcano-hydrothermal systems: the case study of Vulcano (Aeolian Islands, Italy). Pure Appl. Geophys. 169:167-182. http://dx.doi.org/10.1007/s00024-0110297-z

Chiodini, G., Cioni, R., Marini, L., Panichi, C., 1995. Origin of the fumarolic fluids of Vulcano Island, Italy and implications for volcanic surveillance. Bull. Volcanol. 57:99-110. http://dx.doi.org/10.1007/BF00301400.

Chiodini, G., Frondini, F., Cardellini, C., Granieri, D., Marini, L., Ventura, G., 2001. $\mathrm{CO}_{2}$ degassing and energy release at Solfatara volcano, Campi Flegrei, Italy. J. Geophys. Res. Solid Earth 106:16213-16221. http://dx.doi.org/10.1029/2001JB000246

Chiodini, G., Granieri, D., Avino, R., Caliro, S., Costa, A., Werner, C., 2005. Carbon dioxide diffuse degassing and estimation of heat release from volcanic and hydrothermal systems. J. Geophys. Res. Solid Earth 110 (B8). http://dx.doi.org/10.1029/2004JB003542 (B08204).

Chrétien, S., Brousse, R., 1989. Events preceding the great eruption of 8 May, 1902 at Mount Pelée, Martinique. J. Volcanol. Geotherm. Res. 38:67-75. http://dx.doi.org/10. 1016/0377-0273(89)90030-9.

De Astis, G., Lucchi, F., Dellino, P., La Volpe, L., Tranne, C.A., Frezzotti, M.L., Peccerillo, A., 2013. Geology, volcanic history and petrology of Vulcano (central Aeolian archipelago). Geol. Soc. Lond. Mem. 37 (1), 281-349.

Dellino, P., La Volpe, L., 1997. Stratigrafia, dinamiche eruttive e deposizionali, scenario eruttivo e valutazioni di pericolosita`a La Fossa di Vulcano. In: La Volpe, L., Dellino, P., Nuccio, M., Privitera, E., Sbrana, A. (Eds.), Progetto Vulcano: Risultati dell'attività di ricerca 1993-1995. CNR - Gruppo Nazionale per la Vulcanologia. Felici Editore, Pisa, pp. 214-237.

Edmonds, M., Herd, R.A., Galle, B., Oppenheimer, C.M., 2003. Automated, high time-resolution measurements of $\mathrm{SO}_{2}$ flux at Soufrière Hills Volcano. Montserrat. Bull. Volcanol. 65:578-586. http://dx.doi.org/10.1007/s00445-003-0286-x.

Federico, C., Capasso, G., Paonita, A., Favara, R., 2010. Effects of steam heating processes on a stratified volcanic aquifer: stable isotopes and dissolved gases in thermal waters of Vulcano Island (Aeolian archipelago). J. Volcanol. Geotherm. Res. 192:178-190. http://dx.doi.org/10.1016/j.jvolgeores.2010.02.020.

Gambino, S., Guglielmino, F., 2008. Ground deformation induced by geothermal processes: a model for La Fossa Crater (Vulcano Island, Italy). J. Geophys. Res. Solid Earth 113 (B7). http://dx.doi.org/10.1029/2007JB005016.

Gaudin, D., Beauducel, F., Allemand, P., Delacourt, C., Finizola, A., 2013. Heat flux measurement from thermal infrared imagery in low-flux fumarolic zones: example of the Ty fault (La Soufrière de Guadeloupe). J. Volcanol. Geotherm. Res. 267:47-56. http://dx doi.org/10.1016/j.jvolgeores.2013.09.009.

Gaudin, D., Finizola, A., Delcher, E., Beauducel, F., Allemand, P., Delacourt, C., Brothelande E., Peltier, A., Di Gangi, F., 2015. Influence of rainfalls on heat and steam fluxes of fumarolic zones: six months records along the Ty fault (Soufrière of Guadeloupe, Lesser Antilles). J. Volcanol. Geotherm. Res. 302:273-285. http://dx.doi.org/10.1016/j. jvolgeores.2015.06.015.

Gaudin, D., Beauducel, F., Coutant, O., Delacourt, C., Richon, P., de Chabalier, J.-B. Hammouya, G., 2016. Mass and heat flux balance of La Soufrière volcano (Guadeloupe) from aerial infrared thermal imaging. J. Volcanol. Geotherm. Res. 320 107-116. http://dx.doi.org/10.1016/j.jvolgeores.2016.04.007.

Giggenbach, W.F., 1987. Redox processes governing the chemistry of fumarolic gas discharges from White Island, New Zealand. Appl. Geochem. 2:143-161. http://dx.doi. org/10.1016/0883-2927(87)90030-8.

Granieri, D., Carapezza, M.L., Chiodini, G., Avino, R., Caliro, S., Ranaldi, M., Ricci, T., Tarchini, L., 2006. Correlated increase in $\mathrm{CO}_{2}$ fumarolic content and diffuse emission from $\mathrm{La}$ Fossa crater (Vulcano, Italy): evidence of volcanic unrest or increasing gas release from a stationary deep magma body? Geophys. Res. Lett. 33, L13316. http://dx.doi org/10.1029/2006GL026460.

Harris, A., Maciejewski, A., 2000. Thermal surveys of the Vulcano Fossa fumarole field 1994-1999: evidence for fumarole migration and sealing. J. Volcanol. Geotherm. Res. 102:119-147. http://dx.doi.org/10.1016/S0377-0273(00)00184-0.
Harris, A.J.L., Stevenson, D.S., 1997. Thermal observations of degassing open conduits and fumaroles at Stromboli and Vulcano using remotely sensed data. J. Volcanol. Geotherm. Res. 76:175-198. http://dx.doi.org/10.1016/S0377-0273(96)00097-2.

Harris, A.J.L., Lodato, L., Dehn, J., Spampinato, L., 2009. Thermal characterization of the Vulcano fumarole field. Bull. Volcanol. 71:441-458. http://dx.doi.org/10.1007/ s00445-008-0236-8.

Harris, A., Alparone, S., Bonforte, A., Dehn, J., Gambino, S., Lodato, L., Spampinato, L., 2012. Vent temperature trends at the Vulcano Fossa fumarole field: the role of permeability. Bull. Volcanol. 74:1293-1311. http://dx.doi.org/10.1007/s00445-012-0593-1.

Heiken, G., Crowe, B., McGetchin, T., West, F., Eichelberger, J., Bartram, D., Peterson, R., Wohletz, K., 1980. Phreatic eruption clouds: the activity of la Soufrière de Guadeloupe, F.W.I., August-October, 1976. Bull. Volcanol. 43:383-395. http://dx.doi.org/ 10.1007/BF02598039

Inguaggiato, S., Vita, F., Rouwet, D., Bobrowski, N., Morici, S., Sollami, A., 2011. Geochemical evidence of the renewal of volcanic activity inferred from $\mathrm{CO}_{2}$ soil and $\mathrm{SO}_{2}$ plume fluxes: the 2007 Stromboli eruption (Italy). Bull. Volcanol. 73 (4):443-456. http://dx. doi.org/10.1007/s00445-010-0442-z.

Inguaggiato, S., Mazot, A., Diliberto, I.S., Inguaggiato, C., Madonia, P., Rouwet, D., Vita, F., 2012a. Total $\mathrm{CO}_{2}$ output from Vulcano island (Aeolian Islands, Italy). Geochem. Geophys. Geosyst. 13. http://dx.doi.org/10.1029/2011GC003920 (Q02012).

Inguaggiato, S., Calderone, L., Inguaggiato, C., Mazot, A., Morici, S., Vita, F., 2012b. Longtime variation of soil $\mathrm{CO}_{2}$ fluxes at the summit crater of Vulcano (Italy). Bull. Volcanol. 74:1859-1863. http://dx.doi.org/10.1007/s00445-012-0637-6.

Inguaggiato, S., Jacome Paz, M.P., Mazot, A., Delgado Granados, H., Inguaggiato, C., Vita, F., 2013. $\mathrm{CO}_{2}$ output discharged from Stromboli Island (Italy). Chem. Geol. 339:52-60. http://dx.doi.org/10.1016/j.chemgeo.2012.10.008.

Jolivet, J., 1958. La crise volcanique de 1956 à la Soufrière de la Guadeloupe. Ann. Geophys. $14,305$.

Kieffer, H.H., Frank, D., Friedman, J.D. 1981. Thermal infrared surveys at Mount St. Helens - observations prior to the eruption of May 18. US Geol. Surv. Prof. Pap. 1250, 257-277.

Komorowski, J.-C., Legendre, Y., Caron, B., Boudon, G., 2008. Reconstruction and analysis of sub-plinian tephra dispersal during the 1530 A.D. Soufrière (Guadeloupe) eruption: implications for scenario definition and hazards assessment. J. Volcanol. Geotherm. Res. 178:491-515. http://dx.doi.org/10.1016/j.jvolgeores.2007.11.022.

Morgan, P. Blackwell, D.D., Spafford, R.E., Smith, R.B., 1977. Heat flow measurements in Yellowstone Lake and the thermal structure of the Yellowstone Caldera. J. Geophys. Res. 82:3719-3732. http://dx.doi.org/10.1029/JB082i026p03719.

Nicollin, F., Gibert, D., Beauducel, F., Boudon, G., Komorowski, J.-C., 2006. Electrical tomography of La Soufrière of Guadeloupe Volcano: field experiments, 1D inversion and qualitative interpretation. Earth Planet. Sci. Lett. 244:709-724. http://dx.doi.org/10. 1016/j.epsl.2006.02.020.

Nuccio, P.M., Paonita, A., 2001. Magmatic degassing of multicomponent vapors and assessment of magma depth: application to Vulcano Island (Italy). Earth Planet. Sci. Lett. 193:467-481. http://dx.doi.org/10.1016/S0012-821X(01)00512-X.

OVSG-IPGP, 2015. Bulletins mensuels de l'Observatoire volcanologique de la Guadeloupe (1999-2015).

Paonita, A., Federico, C., Bonfanti, P., Capasso, G., Inguaggiato, S., Italiano, F., Madonia, P., Pecoraino, G., Sortino, F., 2013. The episodic and abrupt geochemical changes at La Fossa fumaroles (Vulcano Island, Italy) and related constraints on the dynamics, structure, and compositions of the magmatic system. Geochim. Cosmochim. Acta 120:158-178. http://dx.doi.org/10.1016/j.gca.2013.06.015.

Peltier, A., Finizola, A., Douillet, G.A., Brothelande, E., Garaebiti, E., 2012. Structure of an active volcano associated with a resurgent block inferred from thermal mapping: the Yasur-Yenkahe volcanic complex (Vanuatu). J. Volcanol. Geotherm. Res. 243-244: 59-68. http://dx.doi.org/10.1016/j.jvolgeores.2012.06.022.

Pruppacher, H.R., Klett, J.D., 2000. Microphysics of Clouds and Precipitation. Kluwer Academic Publishers, Dordrecht (The Netherlands).

Revil, A., Finizola, A., Piscitelli, S., Rizzo, E., Ricci, T., Crespy, A., Angeletti, B., Balasco, M., Barde Cabusson, S., Bennati, L., Bolève, A., Byrdina, S., Carzaniga, N., Di Gangi, F., Morin, J., Perrone, A., Rossi, M., Roulleau, E., Suski, B., 2008. Inner structure of La Fossa di Vulcano (Vulcano Island, southern Tyrrhenian Sea, Italy) revealed by highresolution electric resistivity tomography coupled with self-potential, temperature, and $\mathrm{CO} 2$ diffuse degassing measurements. J. Geophys. Res. Solid Earth 113, B07207. http://dx.doi.org/10.1029/2007JB005394.

Ricci, T., Finizola, A., Barde-Cabusson, S., Delcher, E., Alparone, S., Gambino, S., Milluzzo, V., 2015. Hydrothermal fluid flow disruptions evidenced by subsurface changes in heat transfer modality: the La Fossa cone of Vulcano (Italy) case study. Geology G37015: 1. http://dx.doi.org/10.1130/G37015.1.

Robertson, E.C., 1988. Thermal Properties of Rocks. US Department of the Interior, Geological Survey.

Salerno, G.G., Burton, M.R., Oppenheimer, C., Caltabiano, T., Randazzo, D., Bruno, N., Longo, V., 2009. Three-years of $\mathrm{SO}_{2}$ flux measurements of Mt. Etna using an automated UV scanner array: comparison with conventional traverses and uncertainties in flux retrieval. J. Volcanol. Geotherm. Res. 183:76-83. http://dx.doi.org/10.1016/j. jvolgeores.2009.02.013.

Sekioka, M., Yuhara, K., 1974. Heat flux estimation in geothermal areas based on the heat balance of the ground surface. J. Geophys. Res. 79, 2053-2058.

Turcotte, D.L., Schubert, G., 2002. Geodynamics. Cambridge University Press.

Ucciani, G., 2015. Caractérisation spatiale et temporelle de la sismicité volcanique de la Soufrière de Guadeloupe: relation avec le système hydrothermal. PhD dissertation, Paris. 7.

Vilardo, G., Sansivero, F., Chiodini, G., 2015. Long-term TIR imagery processing for spatiotemporal monitoring of surface thermal features in volcanic environment: a case study in the Campi Flegrei (Southern Italy). J. Geophys. Res. Solid Earth. http://dx. doi.org/10.1002/2014JB011497 (2014JB011497). 
Villemant, B., Komorowski, J.C., Dessert, C., Michel, A., Crispi, O., Hammouya, G. Beauducel, F., De Chabalier, J.B., 2014. Evidence for a new shallow magma intrusion at La Soufrière of Guadeloupe (Lesser Antilles): insights from long-term geochemical monitoring of halogen-rich hydrothermal fluids. J. Volcanol. Geotherm. Res. 285: 247-277. http://dx.doi.org/10.1016/j.jvolgeores.2014.08.002.

Vita, F., Inguaggiato, S., Bobrowski, N., Calderone, L., Galle, B., Parello, F., 2012. Continuous $\mathrm{SO}_{2}$ flux measurements for Vulcano Island, Italy. Ann. Geophys. 55. http://dx.doi.org/ 10.4401/ag-5759.

Viveiros, F., Ferreira, T., Cabral Vieira, J., Silva, C., Gaspar, J.L., 2008. Environmental influences on soil $\mathrm{CO}_{2}$ degassing at Furnas and Fogo volcanoes (São Miguel Island, Azores archipelago). J. Volcanol. Geotherm. Res. 177:883-893. http://dx.doi.org/10.1016/j. jvolgeores.2008.07.005 (Volcanic Flows and Falls A Special Issue to Honor Michael F. Sheridan)

Viveiros, F., Vandemeulebrouck, J., Rinaldi, A.P., Ferreira, T., Silva, C., Cruz, J.V., 2014. Periodic behavior of soil $\mathrm{CO}_{2}$ emissions in diffuse degassing areas of the Azores archipelago: application to seismovolcanic monitoring. J. Geophys. Res. Solid Earth 119. http://dx.doi.org/10.1002/2014JB011118 (2014JB011118).

Viveiros, F., Ferreira, T., Silva, C., Vieira, J.C., Gaspar, J.L., Virgili, G., Amaral, P., 2015. Chapter 20 permanent monitoring of soil $\mathrm{CO}_{2}$ degassing at Furnas and Fogo volcanoes (São Miguel Island, Azores). Geol. Soc. Lond. Mem. 44:271-288. http://dx.doi.org/10. 1144/M44.20.

Yuhara, P.D.K., Sekioka, P.D.M., Ehara, D.S., 1978. Infrared measurement on Satsumaiwojima island, Kagoshima, Japan, by helicopter-borne thermocamera. Arch. Für Meteorol. Geophys. Bioklimatol. Ser. A 27:171-181. http://dx.doi.org/10.1007/ BF02246693.

Zanon, V., Frezzotti, M.L., Peccerillo, A., 2003. Magmatic feeding system and crusta magma accumulation beneath Vulcano Island (Italy): evidence from $\mathrm{CO}_{2}$ fluid inclusions in quartz xenoliths. J. Geophys. Res. 108 (B6):2298. http://dx.doi.org/10.1029/ 2002JB002140. 